Original paper

\title{
Beryllium minerals as monitors of geochemical evolution from magmatic to hydrothermal stage; examples from NYF pegmatites of the Třebíč Pluton, Czech Republic
}

\author{
Adam ZACHǍ̌*, Milan NOVÁK, Radek ŠKODA \\ Department of Geological Sciences, Faculty of Sciences, Masaryk University, Kotlářská 2, Brno 611 37, Czech Republic; \\ adamzachar@seznam.cz \\ * Corresponding author
}

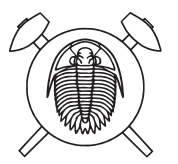

\begin{abstract}
Mineral assemblages of primary and secondary Be-minerals were examined in intraplutonic euxenite-type NYF pegmatites of the Třebíč Pluton, Moldanubian Zone occurring between Třebíč and Vladislav south of the Třebíč fault. Primary magmatic Be-minerals crystallized mainly in massive pegmatite (paragenetic type I) including common beryl I, helvite-danalite I, and a rare phenakite I. Rare primary hydrothermal beryl II and phenakite II occur in miarolitic pockets (paragenetic type II). Secondary hydrothermal Be-minerals replaced primary precursors or filled fractures and secondary cavities, or they are associated with „adularia” and quartz (paragenetic type III). They include minerals of bohseite-bavenite series, less abundant beryl III, bazzite III, helvite-danalite III, milarite-agakhanovite-(Y) III, phenakite III, and datolite-hingganite-(Y) III. Chemical composition of the individual minerals is characterized by elevated contents of $\mathrm{Na}, \mathrm{Cs}, \mathrm{Mg}, \mathrm{Fe}, \mathrm{Sc}$ in beryl I and II; $\mathrm{Na}, \mathrm{Ca}, \mathrm{Mg}, \mathrm{Fe}, \mathrm{Al}$ in bazzite III; REE in milarite-agakhanovite-(Y) III; variations in $\mathrm{Fe} / \mathrm{Mn}$ in helvite-danalite and high variation of $\mathrm{Al}$ in bohseite-bavenite series. Replacement reactions of primary Be-minerals are commonly complex and the sequence of crystallization of secondary Be-minerals is not defined; minerals of bohseite-bavenite series are mostly the latest. Beryl usually occurs in pegmatites with rare tourmaline, whereas helvite-danalite bearing pegmatites are tourmaline-rich. Abundant tourmaline in pegmatites with helvite-danalite and its scarcity in beryl-bearing pegmatites indicate that early tourmaline crystallization affected activity of $\mathrm{Al}$ in the parental medium and thus may have controlled formation of primary Be-minerals (beryl - higher Al, helvite-danalite - lower Al) which crystallized later. Secondary Be-minerals with dominant minerals of bohseite-bavenite series and milarite suggest high activity of Ca in fluids. Variations in chemical composition (Al contents) of bohseite-bavenite series were controlled by the chemical composition of the precursor. High variability of primary magmatic Be-minerals within a single pegmatite district is exceptional and it is constrained by variable activities of Si and mainly $\mathrm{Al}$, divalent cations $-\mathrm{Ca}, \mathrm{Mn}, \mathrm{Fe}, \mathrm{Zn}$ and $\mathrm{Mg}$, trivalent cations $-R E E \mathrm{~s}, \mathrm{Sc}$, and $\mathrm{B}, \mathrm{S}$, and $f_{\mathrm{O} 2}$ in the individual pegmatites.
\end{abstract}

Keywords: beryl, phenakite, helvite-danalite, milarite-and gadolinite-group minerals, bohseite-bavenite, NYF pegmatites, Třebič Pluton Received: 15 April 2020; accepted: 21 July 2020; handling editor: J. Sejkora

The online version of this article (doi: 10.3190/jgeosci.307) contains supplementary electronic material.

\section{Introduction}

Beryllium minerals are typical accessory phases in granitic pegmatites of almost all classes/types defined by Černý and Ercit (2005) with beryl as by far the most abundant primary Be-mineral (e.g., Černý 2002; London 2008). Minor to very rare primary Be-minerals that comprise phenakite, chrysoberyl, gadolinite-, helvite- and rhodizite-group minerals, beryllonite, hurlbutite, hambergite (Černý 2002 and references therein), and primary milarite (Novák et al. 2017) also occur in granitic pegmatites commonly associated with beryl. Primary Be-minerals used to be very often altered to numerous secondary Beminerals as, e.g., bertrandite, bavenite, phenakite, bityite, and milarite (Černý 2002).

High incompatibility of Be in major and most minor and accessory minerals from granitic rocks, caused by the small ionic size and low charge of $\mathrm{Be}^{2+}$, facilitated existence of a broad suite of Be minerals; about 115 minerals with a substantial content of $\mathrm{Be}$, have been described (e.g., Hawthorne and Huminicki 2002; Grew and Hazen 2014). Because of externally imposed chemical potentials that govern the stability of Be-minerals (Barton 1986), the individual Be-minerals may thus serve as sensible geochemical mineral indicators. They can be utilized on this purpose from primary magmatic to secondary hydrothermal stages of granitic pegmatites (e.g., Burt 1978; Markl and Schumacher 1997; Černý 2002; Barton and Young 2002; Franz and Morteani 2002).

Granitic pegmatites of the Třebíč Pluton are a specific type of NYF-affiliated, and they are mostly F-poor pegmatites, which have been derived from ultrapotassic I-type orogenic pluton (Martin and de Vito 2005; Novák et al. 2012; Čopjaková et al. 2013). Beryllium miner- 
als, including primary magmatic, primary hydrothermal and secondary hydrothermal beryl, bazzite, phenakite, helvite-danalite, milarite-group minerals, gadolinitegroup mineral, and bohseite-bavenite series occur in some intragranitic euxenite-type pegmatites (Staněk 1973; Škoda et al. 2006; Novák and Filip 2010). Mixed NYF-LCT Li-bearing pegmatite of Kracovice contains primary hambergite and secondary beryl, bavenite, and bertrandite (Němec 1990; Novák et al. 1998). We examined mineral assemblages, textural relations and chemical composition of $\mathrm{Be}$-minerals from euxenite pegmatites to reveal conditions of their origin, including activities of various elements from primary magmatic to the secondary hydrothermal stage. Also, mineral assemblages of primary Be-minerals from various granitic pegmatites were discussed.

\section{Geological setting}

\subsection{Třebíč Pluton}

The parental granite (melagranite to melasyenite-durbachite) of the examined pegmatites is one of durbachitevaugnerite bodies typical for the European Variscan orogeny (e.g., von Raumer et al. 2014). It forms a large flat body located in the eastern part of the Moldanubian Zone (Fig. 1a; Leichmann et al. 2017). The rock is dominantly coarse-grained, porphyritic, and foliated to various degrees near its contacts with host metamorphic rocks. It is built up of large phenocrysts of orthoclase. Additional minerals comprise $(\mathrm{Fe}, \mathrm{Ti})$-rich phlogopite, oscillatoryzoned plagioclase (An8-40), amphibole (actinolite to rare magnesiohornblende), and quartz, forming mostly a medium-grained matrix. Typical accessory minerals include fluorapatite, zircon, allanite-(Ce), titanite, and sulfide minerals.

The bulk composition of durbachite is characterized by the metaluminous signature (ASI $=0.85-0.93$ ), high concentrations of $\mathrm{K}_{2} \mathrm{O}$ (5.2-6.5 wt. \%), $\mathrm{MgO}$ (3.3-10.4 wt. \%), $\mathrm{P}_{2} \mathrm{O}_{5}(0.47-0.98$ wt. \%), Rb (330-410 ppm), Ba (1100-2470 ppm), U (6.7-26.2 ppm), Th (28.2-47.7 ppm), Cr (270-650 ppm), Cs (20-40 ppm), a high $\mathrm{K} / \mathrm{Rb}$ (133-171), but low $\mathrm{CaO}$ (2.3-4.8 wt. \%) and $\mathrm{Sr}$ contents, and a high $\mathrm{Rb} / \mathrm{Sr}(0.8-1.3)$. The concentrations of Be (6-9 ppm) and B (9-20 ppm) are similar to ordinary granites (e.g., London and Evensen 2002). Both geochemical signature, as well as the isotopic $\mathrm{Sr}$ $\left({ }^{87} \mathrm{Sr} /{ }^{86} \mathrm{Sr}_{337}=0.709-0.7125\right)$ and $\mathrm{Nd}\left({ }^{337} \mathrm{Nd}=-6.3\right)$ data suggest mixing of a durbachitic magma with (leuco)granitic melt derived from crustal rocks undergoing anatexis during rapid decompression (for details, see, e.g., Holub 1997; Janoušek et al. 2003; Breiter 2008; Janoušek et al. 2019). Radiometric dating of the durbachite (U/Pb zir-

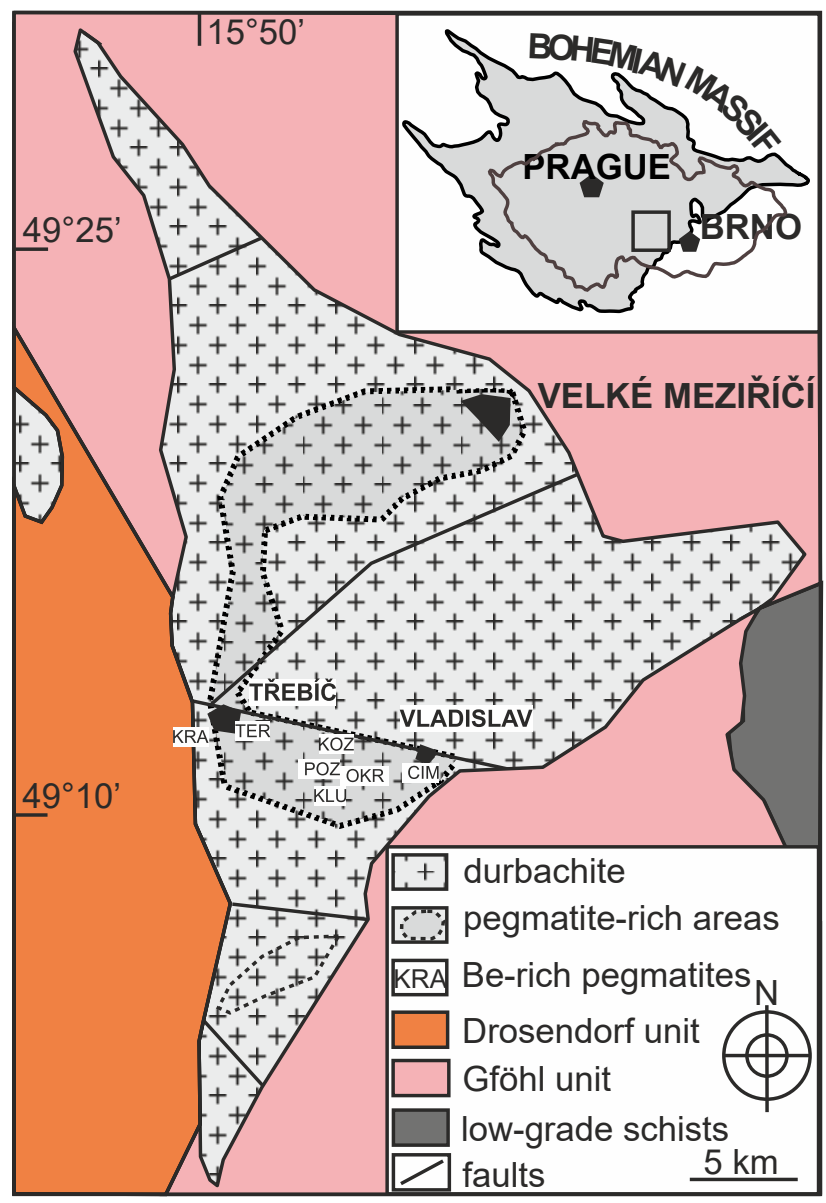

Fig. 1 Simplified geological map of Třebíč Pluton with marked position of studied pegmatites: TER - Terůvky; KOZ - Kožichovice I,II; POZ - Pozd’átky; KLU - Klučov III; OKR - Okrašovice; CIM - Číměř I,II; KRA - Kracovice.

con) yielded ages of 342-335 Ma (Janoušek et al. 2020 and references therein).

\subsection{Granitic pegmatites}

Pegmatites of the Třebíc Pluton have been divided based on their mineral assemblages, degree of geochemical fractionation and internal structure into several groups: (i) geochemically primitive allanite-type pegmatites, and (ii) more evolved euxenite-type pegmatites (Novák et al. 1999, 2012; Škoda et al. 2006; Škoda and Novák 2007; Zachař and Novák 2013). (iii) The highly evolved, Li, $R E E$-bearing pegmatite from Kracovice, the only known extragranitic pegmatite, which cuts gneisses $\sim 0.5 \mathrm{~km}$ to the W of the Trrebíč Pluton (Němec 1990; Novák et al. 1999, 2012) has not been examined. The first two pegmatite types relate to the REL-REE subclass, a rareelements class of the NYF family (Černý and Ercit 2005). Nevertheless, they are F-poor and do not entirely fit the definition of NYF family (Simmons et al. 2012), whereas the (iii) Kracovice represents mixed NYF-LCT pegmatite 
(Novák et al. 1999; Černý and Ercit 2005; Novák et al. 2012; Čopjaková et al. 2015). Martin and De Vito (2005) considered pegmatites of Třebíc Pluton to be NYFrelated, and to a specific type of pegmatite derived from ultrapotassic orogenic pluton belonging to a shoshonitic association (see Žák et al. 2005).

The euxenite-type pegmatites form subverticallyzoned dikes, $\sim 0.2-1 \mathrm{~m}$ thick, and typically show a transitional contact with the host durbachite. Their internal structure comprises (from the contact inward): a border/ wall zone of medium- to coarse-grained granitic unit $(\mathrm{Kfs}+\mathrm{Qz}+\mathrm{Plg}+\mathrm{Phl} \pm \mathrm{Amp} \pm \mathrm{Tur})$, a graphic unit $(\mathrm{Kfs}+\mathrm{Qz}$ $>\mathrm{Ab}+\mathrm{Qz}$ ), a blocky K-feldspar unit (locally pale green amazonite) and a quartz core (Fig. 2). A medium- to coarse-grained albite unit is locally found in nests, up to $10 \mathrm{~cm}$ in diameter, typically developed between blocky $\mathrm{K}$-feldspar and quartz core. Rare small pockets with crystals of quartz, K-feldspar, and albite were found in some dikes. Along with the aforementioned phlogopite, most pegmatites contain minor to rare accessory black tourmaline (Ca, Ti-rich, Al-poor schorl-dravite; Novák et al. 2011) and common to rare accessory minerals. These include titanite, allanite-(Ce), pyrite, ilmenite, pseudorutile, niobian rutile, zircon, $R E E, \mathrm{Nb}, \mathrm{Ta}$, Ti-oxide minerals, and beryl (Novák and Čech 1996; Škoda et al. 2006; Škoda and Novák 2007; Novák and Filip 2010). The euxenite-type pegmatites with Beminerals are located exclusively south of the Třebíč fault in the W-E trending belt from Třebić to Vladislav (Fig. 1b). Unfortunately, a flat landscape in the area of the Třebič Pluton provided only several well-exposed outcrops, and some Be-minerals are known only in rock fragments from agricultural fields. Chemical composition of the individual units of the euxenite-type is characterized by high $\mathrm{Si}\left(75.74-76.51\right.$ wt. $\left.\% \mathrm{SiO}_{2}\right)$, moderate $\mathrm{Al}$ (13.04-13.08 wt. $\% \mathrm{Al}_{2} \mathrm{O}_{3}$ ), ASI (1.02-1.09), dominance of $\mathrm{K}_{2} \mathrm{O}$ over $\mathrm{Na}_{2} \mathrm{O}$ (5.58-7.46 wt. \%, 2.55-3.25 wt. \%, respectively), low $\mathrm{CaO}(0.11-0.78$ wt. \%) and very low $\mathrm{P}_{2} \mathrm{O}_{5}(0.02$ wt. \%). Trace elements gave $\mathrm{Ba}$ (197-947 ppm), Rb (222-297 ppm), U (3.5-28.6 ppm) and Th (15.4-31.6 ppm), Be (11-42 ppm), B (24-68 ppm) and F (90-110 ppm) (Čopjaková et al. 2013).

\section{Samples and methods}

The samples studied in detail come from the field research of the authors starting in early 2000ies, including very recently (2016-2019) discovered localities (Číměr I, Č́měř II, Okrašovice, and Klučov III). Only a small part of the samples was taken from the collection of the Moravian Museum, Brno, collected in the 1950ies to 1980ies. They represent unique mineral assemblages of Be-minerals; however, some are known only from frag-

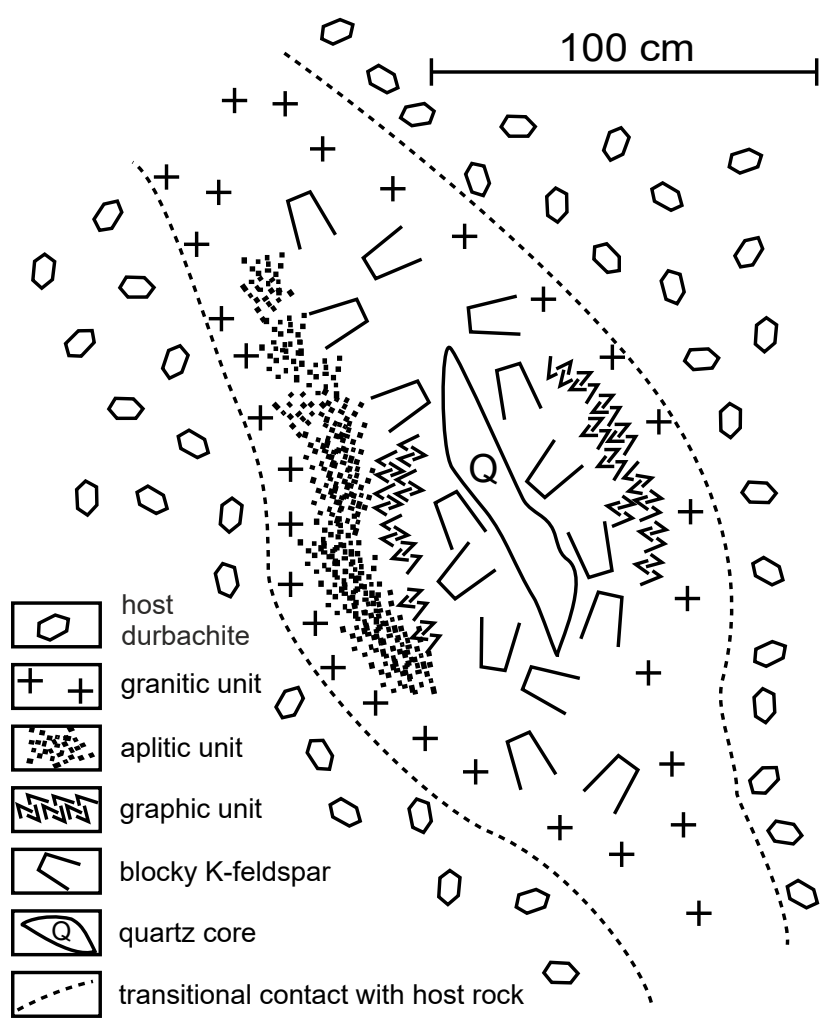

Fig. 2 Simplified cross-section of euxenite pegmatite from Třebíč Pluton. Slightly modified from Škoda et al. (2006).

ments and geology, and mineral assemblages of their parental pegmatite bodies are poorly known.

Used terms: for examined and associating minerals in text and figures following abbreviations have been used. $\mathrm{Boh}=$ bohseite, $\mathrm{Bvn}=$ bavenite, $\mathrm{Bz}=$ bazzite, $\mathrm{Hlv}=$ helvite (-danalite), $\mathrm{Mil}=$ milarite, $\mathrm{Ph}=$ phenakite. Other abbreviations are after Whitney and Evans (2010).

\subsection{Electron-probe microanalysis (EPMA)}

Chemical compositions of studied minerals were determined by means of the Cameca SX100 electron microprobe at the Laboratory of Electron Microscopy and Microanalysis, Department of Geological Sciences, Masaryk University, Brno in wavelength dispersive mode and the accelerating voltage $15 \mathrm{kV}$, beam current $10 \mathrm{nA}$ and a spot size $\sim 5 \mu \mathrm{m}$. The following standards and X-ray $K_{\alpha}$ lines were used: sanidine ( $\left.\mathrm{Si}, \mathrm{Al}, \mathrm{K}\right)$, albite (Na), olivine $(\mathrm{Mg})$, wollastonite $(\mathrm{Ca})$, almandine $(\mathrm{Fe})$, spessartine $(\mathrm{Mn})$, fluorapatite $(\mathrm{P})$, titanite $(\mathrm{Ti})$, chromite $(\mathrm{Cr})$, topaz (F), gahnite (Zn), $\mathrm{SrSO}_{4}(\mathrm{~S})$. The peak counting time was 10 seconds for major elements and 20-40 seconds for minor to trace elements. The background counting time was $1 / 2$ of the peak counting time on the high- and low-energy background-position. Raw intensities were corrected for matrix effects using the $X$-PHI algorithm (Merlet 1994). The theoretical amount of unanalyzed 
light elements $(\mathrm{H}, \mathrm{Be}, \mathrm{B})$ was included in the matrix correction procedure. For analysis of REE-bearing minerals, the conditions described in Novák et al. (2017), and Škoda et al. (2018) were used.

Results obtained from EPMA were calculated as following: $T=6$ atoms (beryl group); $\mathrm{Si}=3$ apfu (helvite group); $\mathrm{Si}=2$ apfu, $B=\mathrm{Ca}, \mathrm{Be}=2-B$ (gadolinite group); $\mathrm{Si}=12$ apfu (milarite group); $\mathrm{Si}=9$ apfu (bohseitebavenite series).

\subsection{Rare Earth Elements terminology}

According to the International Union for Pure and Applied Chemistry, the term rare-earth elements (REEs) includes lanthanoids (Ln), yttrium (Y), and scandium $(\mathrm{Sc})$. Due to the substantially smaller ionic radius of Sc concerning the rest of the group, it frequently enters different crystal-structural sites via different substitutions. Therefore, $\mathrm{Sc}$ is commonly not included in the REEs in geological sciences, and neither in this paper. Due to the lanthanide contraction phenomenon, the REEs are further divided into larger $L R E E$ (light $\mathrm{Ln}, \mathrm{La}-\mathrm{Gd}$ ) and smaller HREE (heavy Ln, Tb-Lu, and Y).

\section{Results}

\subsection{Mineral assemblages of the examined pegmatites}

The internal structure, as well as the shape and size of the examined euxenite pegmatite dikes with Be-minerals (Tab. 1), are similar to the pegmatites described in the subchapter 2.2. (see also Škoda et al. 2006; Novák and Filip 2010; Novák et al. 2011; Čopjaková et al. 2013). Accessory minerals, including primary Be-minerals from the examined localities, are given in Tab. 1. Tourmaline is the most abundant minor to accessory mineral along with major constituents - feldspars and quartz (Tab. 1). It is very rare or even absent in beryl-bearing pegmatites, and, on the other hand, abundant in helvite-danalite bearing pegmatites. The following textural-paragenetic types of

Tab. 1 Primary minor and accessory minerals from the examined pegmatites

\begin{tabular}{|c|c|c|c|c|c|c|c|c|c|}
\hline Family & $\begin{array}{l}\text { Pegmatite } \\
\text { type }\end{array}$ & $\begin{array}{c}\text { Mineral } \\
\text { assemblage }\end{array}$ & $\begin{array}{c}\text { Locality } \\
\text { (abbreviation) }\end{array}$ & Field setting & $\begin{array}{c}\text { Primary } \\
\text { Be-minerals }\end{array}$ & Tourmaline & Micas & $\begin{array}{l}\text { Accessory } \\
\text { minerals }\end{array}$ & References \\
\hline \multirow{10}{*}{ NYF } & allanite & & many & outcorps/blocks & absent & absent to +++ & $\mathrm{Bt}$ & $\begin{array}{l}\text { Aln, Ttn, } \\
\text { Zrn, Ilm }\end{array}$ & $1,2,3,4$ \\
\hline & \multirow{9}{*}{ euxenite } & \multirow{6}{*}{$\begin{array}{c}\mathrm{BP} \\
\text { assemblage }\end{array}$} & Vladislav & outcrop & absent & + & $\mathrm{Bt}$ & $\begin{array}{l}\text { EGM, Aln, } \\
\text { Mnz, Ilm, } \\
\text { Zrn }\end{array}$ & 1,2 \\
\hline & & & Okrašovice (Okr) & large blocks & beryl I & ++ & $\mathrm{Bt}$ & $\begin{array}{c}\text { EGM, Aln, } \\
\text { Ilm, Zrn }\end{array}$ & 4 \\
\hline & & & $\begin{array}{c}\text { Kožichovice I } \\
\text { (KozI) }\end{array}$ & outcrop & beryl I & + & $\mathrm{Bt}$ & $\mathrm{Ilm}$ & this study \\
\hline & & & $\begin{array}{c}\text { Kožichovice II } \\
\text { (KozII) }\end{array}$ & outcrop & $\begin{array}{l}\text { beryl I >> } \\
\text { phenakite I }\end{array}$ & + & $\mathrm{Bt}$ & $\begin{array}{c}\text { AGM, } \\
\text { Nb-rutile, } \\
\text { CGM, Py, } \\
\text { Aln, Ttn, } \\
\text { Ilm, Zrn }\end{array}$ & 3,5 \\
\hline & & & Pozd'átky & fragment & beryl II & + & $?$ & $\mathrm{Ilm}$ & this study \\
\hline & & & Terůvky (Ter) & fragment & phenakite II & $?$ & $?$ & $?$ & 6 \\
\hline & & \multirow{3}{*}{$\begin{array}{c}\text { HDP } \\
\text { assemblage }\end{array}$} & Klučov III (KluIII) & outcrop & $\begin{array}{c}\text { helvite I }> \\
\text { phenakite I }\end{array}$ & +++ & $\mathrm{Bt}$ & AGM, Cst & this study \\
\hline & & & Číměř II (CimII) & outcrop & helvite I & +++ & $\mathrm{Bt}$ & Aln & this study \\
\hline & & & Číměř I (CimI) & outcrop & $\begin{array}{l}\text { helvite I }> \\
\text { phenakite I } \\
\text { >> beryl I }\end{array}$ & +++ & $\mathrm{Bt}$ & $\begin{array}{c}\text { AGM, Cst, } \\
\text { CGM, Apy, } \\
\text { Po, PGM, } \\
\text { Zrn }\end{array}$ & this study \\
\hline $\mathrm{NYF}+\mathrm{LCT}$ & & & Kracovice (Krc) & outcrop & hambergite & +++ & $\begin{array}{l}\text { Lpd, } \\
\mathrm{Ms}, \mathrm{Bt}\end{array}$ & $\begin{array}{c}\text { FGM, SGM, } \\
\text { Aln, Sps, } \\
\text { Tpz, Mnz, } \\
\text { Xtm, Cst, } \\
\text { Zrn } \\
\end{array}$ & $7,8,9,10,11$ \\
\hline
\end{tabular}

in bold - examined in detail; + rare, ++ common, +++ abundant

AGM - aeschynite-group minerals, EGM - euxenite-group minerals, CGM - columbite-group minerals, FGM - fergusonite-group minerals, SGM - samarskite-group minerals, PGM - pyrochlore-group minerals

1 - Škoda and Novák (2007), 2 - Škoda et al. (2006), 3 - Novák et al. (2011), 4 - Čopjaková et al. (2013), 5 - Novák and Filip (2010), 6 - Staněk (1973), 7 - Čopjaková et al. (2015), 8 - Němec (1990), 9 - Novák et al. (2012), 10 - Novák et al. (1999), 11 - Novák (2005) 
tourmaline occur in the aplite, coarse-grained, and blocky pegmatite units: rare prismatic crystals to anhedral grains and their aggregates, graphic intergrowths with quartz and common, interstitial fillings (for more details see Novák et al. 2011; Čopjaková et al. 2013). Also, REE, $\mathrm{Nb}$, Ta, Ti-oxide minerals, and allanite-(Ce) were found at most localities, whereas titanite and ilmenite occur mainly in pegmatites where tourmaline is rare. Less common Sn-minerals (cassiterite, herzenbergite, stokesite), columbite group minerals and $\mathrm{Nb}$-rutile are typical for the most evolved pegmatites (e.g., Číměř I, Kožichovice II). Apatite and REE-phosphates, monazite-(Ce) and xenotime-(Y), are very rare (Tab. 1).

\subsection{Mineral assemblages and textural relations of primary and secondary Be-minerals}

The detailed study revealed new mineral assemblages of primary and secondary Be-minerals different from those described to date by Staněk (1973), Škoda et al. (2006), and Novák and Filip (2010). Three distinct paragenetic types of Be-minerals were defined: type I - primary magmatic Be minerals in massive pegmatite: beryl I, phenakite I, and helvite-danalite I; type II - rare primary hydrothermal minerals from miarolitic pockets: beryl II, phenakite II; type III - proximal secondary hydrothermal minerals directly replacing primary Be-minerals and distal ones filling fractures or small secondary vugs near primary Be-minerals: beryl III, phenakite III, milarite-agakhanovite III, bohseite-bavenite series III, and bazzite III. Rare quartz + adularia veinlets/masses with milarite-agakhanovite III and gadolinite-group mineral III belong to the type III. However, their paragenetic position and origin are worth for more detailed study. Note, the suffix (I, II, III) indicates the paragenetic type and not the generation of the mineral.

\subsubsection{Primary minerals}

We used the designation "a primary Be-mineral" for all Be-minerals, which crystallized ambiguously during the primary (magmatic) stage. They appear in the euhedral to subhedral crystals, and their aggregates are embedded in a massive pegmatite. They include beryl I, phenakite I, helvite-danalite I (Tab. 1). Furthermore, very rare euhedral beryl II and phenakite II that crystallized into opened miarolitic cavities (Tab. 2) are considered as minerals of primary origin as well.

Primary minerals in the euxenite-type pegmatites (beryl I $\sim$ helvite-danalite I > phenakite I) are commonly enclosed in central parts of the dikes in a coarse-grained pegmatite (blocky $\mathrm{Kfs}+\mathrm{Qz}+\mathrm{Ab}$; beryl, helvite-danalite, phenakite), in massive quartz (phenakite), in masses of albite (beryl), scarcely in the graphic unit (helvite-danalite) and in rare primary pockets (beryl II, phenakite II; Tab. 2). In beryl pegmatites, beryl I forms pale green to yellowish prismatic crystals, up to $8 \mathrm{~cm}$ long and $5 \mathrm{~mm}$ thick, and their radial aggregates. Chloritized phlogopite, aeschynite-group minerals, and pyrite were found closely associated with or enclosed in some beryl crystals. In the BSE images and thin sections, primary beryl I forms elongated prismatic crystals with well-developed zoning (Fig. 3a). Microscopic inclusions of clay minerals and secondary Be-minerals (beryl III, bohseite-bavenite series III, milarite III, bazzite III) in veinlets and nest aggregates are common (Fig. 3b). Less abundant long prismatic crystals of colorless phenakite I, up to $3 \mathrm{~cm}$ long and $0.5 \mathrm{~cm}$ thick (Tab. 1), are typically fresh comparing beryl I; however, due to their quartz-like appearance and mostly lack of alteration phenakite may be easily overlooked.

Primary brown to red Fe-rich helvite I to Mn-rich danalite I was found in coarse-grained pegmatite (blocky $\mathrm{K}$-feldspar $+\mathrm{Qz}>\mathrm{Ab})$ and graphic unit (Kfs $+\mathrm{Qz})$ as subhedral grains up to $5 \mathrm{~cm}$ in size in helvite-danalite

Tab. 2 Paragenetic types of primary and secondary Be-minerals

\begin{tabular}{|c|c|c|c|c|}
\hline \multirow{3}{*}{ Be-minerals } & \multicolumn{3}{|c|}{ Primary } & \multirow{3}{*}{$\begin{array}{c}\text { Secondary } \\
\text { Proximal/distal }\end{array}$} \\
\hline & \multicolumn{2}{|c|}{ Massive pegmatite } & \multirow[t]{2}{*}{ Miaroles } & \\
\hline & Qz, Kfs & $\mathbf{A b}$ & & \\
\hline Paragenetic type & I & I & II & III \\
\hline Beryl/beryl* & Koz II, Okr, Poz I, Cim I & Koz II & $\mathrm{Poz}$ & Koz I, Koz II, Cim I, Krc \\
\hline Phenakite/phenakite & Koz II, Cim I, Klu III & Cim I & Ter & Okr, Koz II \\
\hline Helvite-danalite/danalite & Cim I, Cim II, Klu III & Cim I & & Cim I \\
\hline Milarite/milarite & Cim I & & Cim I & Koz I, Koz II, Cim I, Klu III \\
\hline Hingganite-(Y) & & & Cim I & \\
\hline Hambergite & $\mathrm{Krc}$ & $\mathrm{Krc}$ & & \\
\hline Bazzite & & & & Koz I, Koz II \\
\hline Bavenite-bohseite & & & & Koz I, Koz II, Cim I, Klu III, Krc \\
\hline Bertrandite & & & & $\mathrm{Krc}$ \\
\hline
\end{tabular}

* Secondary minerals in italics

data from Kracovice in Němec (1990) 


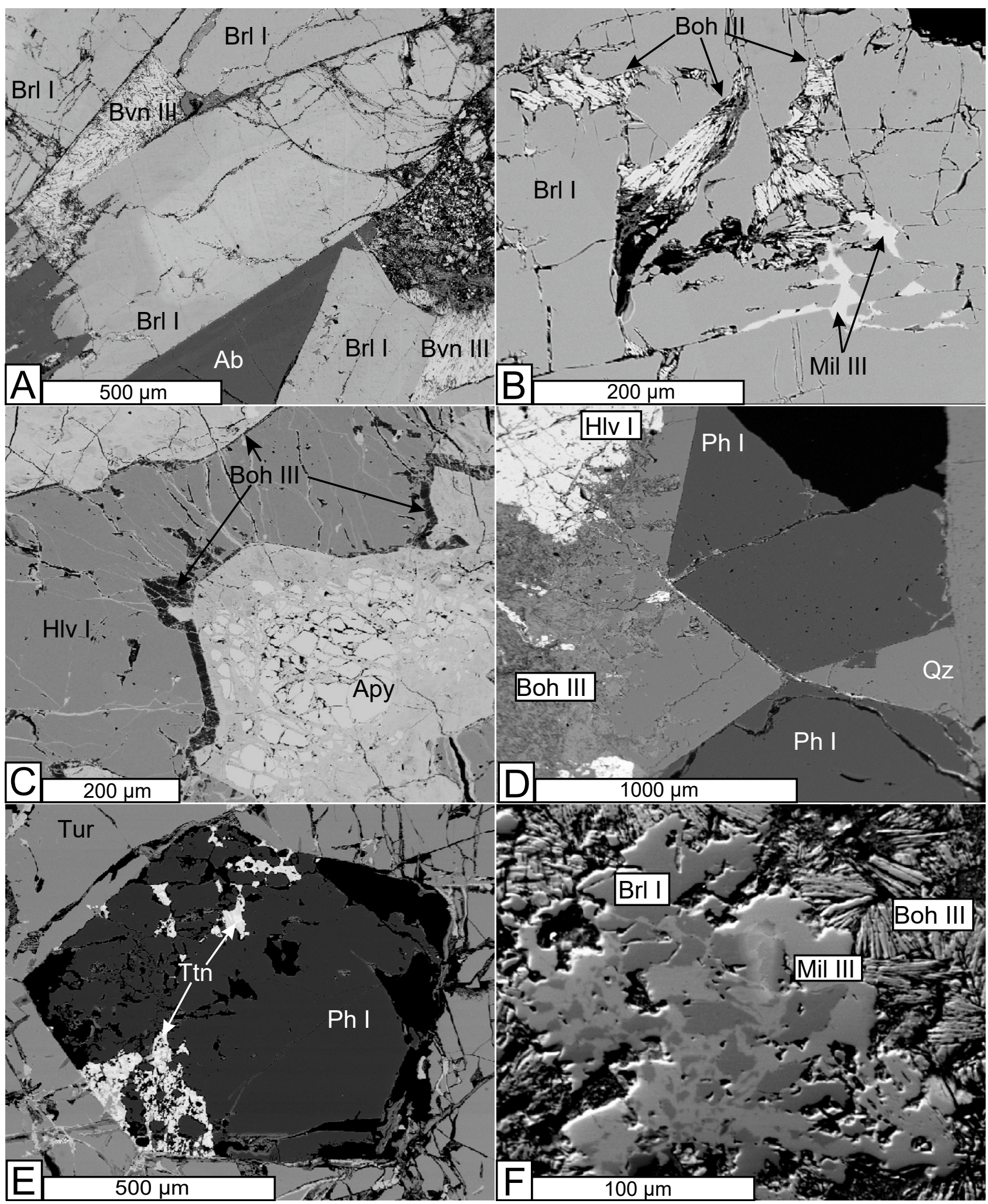

Fig. 3 BSE images of primary Be-minerals from beryl pegmatites (A, B) and helvite-danalite pegmatites (C-F). A - zoned beryl I partly replaced by bavenite-bohseite, Kožichovice II. B - fans of bavenite-bohseite III and milarite III veinlets in beryl I, Kožichovice II. C - helvite-danalite I rimmed by bohseite associating with arsenopyrite replaced by pharmacosiderite, Číměr I. D - euhedral phenakite I and helvite I altered to bohseite III, Číměř I. E - phenakite I embedded in tourmaline and crosscut by Ta-titanite, Číměr̆ I. F - milarite III replacing beryl I, in association with bohseite III, Č́méř I. 


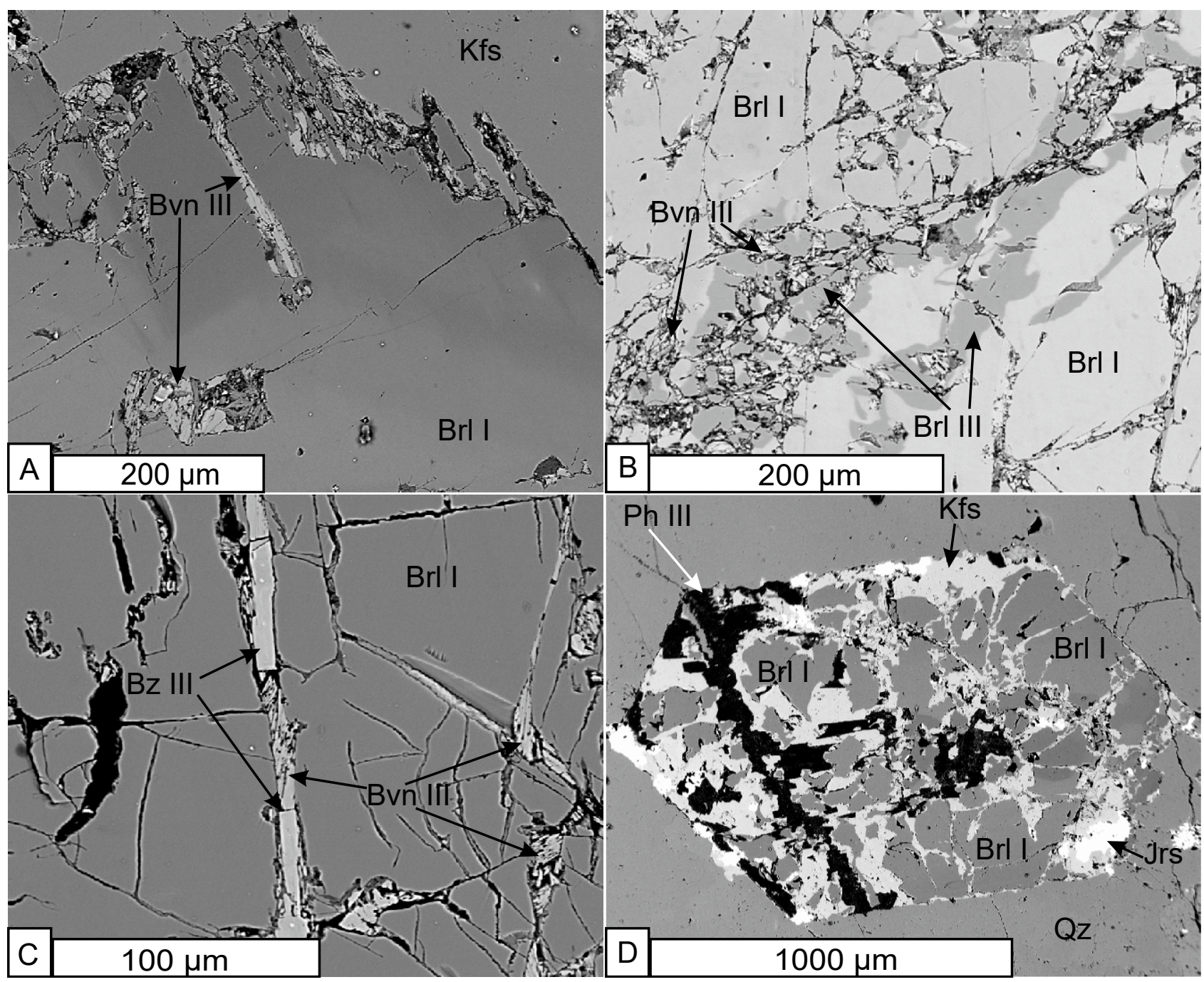

Fig. 4 BSE images of secondary Be-minerals from beryl pegmatites. A - beryl I replaced by bavenite-bohseite III along with termination of crystal, Kožichovice II. B - zoned beryl I crosscut by veinlets of beryl III, Kožichovice II. C - bazzite III laths enclosed in bavenite III veinlet, crosscutting beryl I, Kožichovice II. D - euhedral beryl I in quartz replaced by K-feldspar, phenakite III and jarosite, Okrašovice.

pegmatites (Tab. 2). They are locally associated with arsenopyrite (Fig. 3c) and typically covered by black Mn-oxides. Phenakite I can be present in association with helvite-danalite (Fig. 3d), and tourmaline (Fig. 3e) or occurs solely in quartz from central parts of pegmatite body as prismatic crystals, up to $15 \mathrm{~mm}$ long. Scarcely, small relics $(<100 \mu \mathrm{m})$ of intensively corroded beryl I (Fig. 3f), which is replaced by milarite, were observed in the association with phenakite I, adularia and bohseitebavenite III.

Both very rare yellowish beryl II and a colorless phenakite II occur in scarce primary miarolitic pockets. They are lined with crystals of K-feldspar (locally amazonite), quartz and albite. The former as short prismatic crystals, up to $5 \mathrm{~mm}$ long, and the latter as tabular crystals, up to 5 mm in size, respectively (Tab. 2; Staněk 1973).

Two principal mineral assemblages can be distinguished on the base of a dominant primary Be-mineral in euxenite-type pegmatites (disregarding scarce minerals from pockets as beryl II, phenakite II). It is the BP assemblage (beryl $\mathrm{I} \pm$ phenakite I) that occurs exclusively in beryl pegmatites. On the other hand, the HDP assemblage (helvite-danalite I $>$ phenakite I $\gg>> \pm$ beryl I) is restricted to helvite-danalite pegmatites (Tab. 1). Apart from different Be-minerals assemblage, a further distinctive feature is a scarcity and abundance of magmatic tourmaline in beryl and helvite-danalite pegmatites, respectively.

\subsubsection{Secondary minerals}

Beryl I from the BP assemblage is commonly replaced by bohseite III to rare bavenite III (bohseite-bavenite series) as platy crystals or fine-grained filling of thin veinlets and small nests within beryl I grains or along their boundaries (Fig. 4a). Rare beryl III is known as veinlets in grains of 
Tab. 3 Representative analyses of the beryl-group minerals

\begin{tabular}{|c|c|c|c|c|c|c|c|c|c|}
\hline \multirow{2}{*}{$\begin{array}{l}\text { Assemblage } \\
\text { Locality }\end{array}$} & \multicolumn{7}{|c|}{$\mathrm{BP}$} & \multicolumn{2}{|c|}{ HDP } \\
\hline & OKR & KOZ I & KOZ II & POZ & KOZ II & KOZ II & KOZ II & ČIM I & ČIM I \\
\hline & Brl I & Brl I & Brl I & Brl II & Brl III & Bz III & Bz III & Brl I & Brl I \\
\hline & 1 & 2 & 3 & 4 & 5 & 6 & 7 & 8 & 9 \\
\hline $\mathrm{SiO}_{2}$ & 64.80 & 63.62 & 63.69 & 65.92 & 65.95 & 58.37 & 58.82 & 65.34 & 63.72 \\
\hline $\mathrm{TiO}_{2}$ & 0.00 & 0.00 & 0.00 & 0.00 & 0.00 & 0.10 & 0.00 & 0.00 & 0.00 \\
\hline $\mathrm{Al}_{2} \mathrm{O}_{3}$ & 14.59 & 12.96 & 14.29 & 14.48 & 15.64 & 2.15 & 0.17 & 15.97 & 12.86 \\
\hline $\mathrm{Sc}_{2} \mathrm{O}_{3}$ & 0.23 & 0.31 & 0.13 & 0.09 & 0.22 & 13.17 & 15.81 & 0.00 & 0.00 \\
\hline $\mathrm{V}_{2} \mathrm{O}_{3}$ & 0.01 & 0.10 & 0.00 & 0.00 & 0.00 & 0.05 & 0.10 & 0.00 & 0.00 \\
\hline $\mathrm{MgO}$ & 2.19 & 2.61 & 2.34 & 2.29 & 1.54 & 3.04 & 2.56 & 0.70 & 2.03 \\
\hline $\mathrm{CaO}$ & 0.00 & 0.06 & 0.00 & 0.03 & 0.09 & 2.50 & 0.36 & 0.05 & 0.32 \\
\hline $\mathrm{MnO}$ & 0.05 & 0.03 & 0.00 & 0.02 & 0.06 & 0.26 & 0.26 & 0.00 & 0.00 \\
\hline $\mathrm{FeO}_{\text {tot }}$ & 1.13 & 1.11 & 0.81 & 1.02 & 0.37 & 1.45 & 1.93 & 1.41 & 3.55 \\
\hline $\mathrm{Na}_{2} \mathrm{O}$ & 1.24 & 1.57 & 1.60 & 1.49 & 1.33 & 2.36 & 2.24 & 0.89 & 1.74 \\
\hline $\mathrm{K}_{2} \mathrm{O}$ & 0.36 & 0.44 & 0.32 & 0.39 & 0.04 & 0.01 & 0.00 & 0.00 & 0.13 \\
\hline $\mathrm{Rb}_{2} \mathrm{O}$ & 0.14 & 0.14 & 0.17 & 0.00 & 0.08 & 0.00 & 0.12 & 0.09 & n.d. \\
\hline $\mathrm{Cs}_{2} \mathrm{O}$ & 1.12 & 1.35 & 0.51 & 0.59 & 0.09 & 0.38 & 0.81 & 0.22 & n.d. \\
\hline$* \mathrm{BeO}$ & 13.51 & 13.12 & 13.19 & 13.46 & 13.62 & 12.41 & 12.29 & 13.25 & 13.26 \\
\hline$* * \mathrm{H}_{2} \mathrm{O}$ & 1.89 & 2.17 & 2.20 & 2.10 & 1.97 & 2.84 & 2.74 & 1.59 & 2.32 \\
\hline Total & 101.20 & 99.60 & 99.29 & 102.06 & 100.99 & 99.04 & 98.19 & 99.75 & 99.93 \\
\hline \multicolumn{10}{|l|}{ apfu } \\
\hline $\mathrm{Si}^{4+}$ & 6.000 & 6.000 & 6.000 & 6.000 & 6.000 & 6.000 & 6.000 & 6.000 & 6.000 \\
\hline $\mathrm{Ti}^{4+}$ & 0.000 & 0.000 & 0.000 & 0.000 & 0.000 & 0.008 & 0.000 & 0.000 & 0.000 \\
\hline $\mathrm{Al}^{3+}$ & 1.593 & 1.441 & 1.587 & 1.553 & 1.677 & 0.260 & 0.021 & 1.729 & 1.427 \\
\hline $\mathrm{Sc}^{3+}$ & 0.018 & 0.025 & 0.010 & 0.007 & 0.017 & 1.180 & 1.405 & 0.000 & 0.002 \\
\hline $\mathrm{V}^{3+}$ & 0.001 & 0.007 & 0.000 & 0.000 & 0.000 & 0.004 & 0.007 & 0.000 & 0.000 \\
\hline $\mathrm{Mg}^{2+}$ & 0.302 & 0.367 & 0.329 & 0.311 & 0.209 & 0.466 & 0.390 & 0.096 & 0.284 \\
\hline $\mathrm{Ca}^{2+}$ & 0.000 & 0.006 & 0.000 & 0.003 & 0.009 & 0.275 & 0.040 & 0.005 & 0.032 \\
\hline $\mathrm{Mn}^{2+}$ & 0.004 & 0.002 & 0.000 & 0.002 & 0.005 & 0.023 & 0.022 & 0.000 & 0.009 \\
\hline $\mathrm{Fe}^{2+}$ & 0.087 & 0.088 & 0.064 & 0.078 & 0.028 & 0.125 & 0.165 & 0.108 & 0.280 \\
\hline $\mathrm{Na}^{+}$ & 0.222 & 0.287 & 0.292 & 0.263 & 0.235 & 0.470 & 0.443 & 0.158 & 0.318 \\
\hline $\mathrm{K}^{+}$ & 0.042 & 0.053 & 0.038 & 0.045 & 0.005 & 0.001 & 0.000 & 0.000 & 0.016 \\
\hline $\mathrm{Rb}^{+}$ & 0.008 & 0.008 & 0.010 & 0.000 & 0.005 & 0.007 & 0.008 & 0.005 & n.d. \\
\hline $\mathrm{Cs}^{+}$ & 0.044 & 0.054 & 0.020 & 0.023 & 0.003 & 0.017 & 0.035 & 0.009 & n.d. \\
\hline $\mathrm{Be}^{2+}$ & 3 & 3 & 3 & 3 & 3 & 3 & 3 & 3 & 3 \\
\hline $\mathrm{H}^{+}$ & 1.166 & 1.379 & 1.383 & 1.286 & 1.205 & 1.935 & 1.864 & 0.985 & 1.458 \\
\hline $\mathrm{O}^{2-}$ & 17.964 & 17.944 & 17.979 & 17.949 & 17.916 & 18.253 & 17.999 & 17.955 & 17.921 \\
\hline
\end{tabular}

beryl I (Fig. 4b), prismatic crystals, up to $100 \mu \mathrm{m}$ long, in bohseite-bavenite aggregates and as thin alteration zones between beryl I and secondary bohseite-bavenite masses. Rare prismatic crystals of bazzite III, up to $50 \mu \mathrm{m}$ long (Fig. 4c), are typically embedded in some bohseitebavenite aggregates in beryl I (see also Novák and Filip 2010). Chlorites, epidote-clinozoisite, albite, and quartz are locally associated mainly with minerals of bohseitebavenite series. Milarite III is typically located in quartzand phenakite-hosted cavities and locally is crosscut by bohseite III veinlets. Rare phenakite III forms veinlets in beryl I locally associated with late K-feldspar (Fig. 4d).

In the HDP assemblage, helvite-danalite $\mathrm{I}$ is altered to abundant bohseite III to rare Al-poor bavenite III (Figs
$5 \mathrm{a}, \mathrm{b})$. They associate with axinite, which fills fissures and voids distally from the altered helvite-danalite. Scarce danalite III partially replaces and fills secondary vugs in primary helvite I, and no other associated secondary Beminerals have been observed (Fig. 5c). Phenakite I and

Fig. 5 BSE images of secondary Be-minerals helvite-danalite pegmatites. A - helvite-danalite I replaced by bohseite III, Číměř I. B - bohseite III fills the euhedral cavity in helvite-danalite I, Číměr̆ I. C - helvite-danalite I replaced by Zn-rich danalite III, Č́měř I. D - zoned (REE-) milarite III in porous quartz veinlet, Číměr̆ I. E - bohseite III aggregate in the cavity, Číměr̆ I. F - bohseite III penetrating phenakite I, Klučov III. G - milarite-agakhanovite (Mil III) overgrowths on pyrochlore $(\mathrm{Pcl})$, Číměř I. H - sector-zoning of gadolinite-group mineral, Číměř I. 


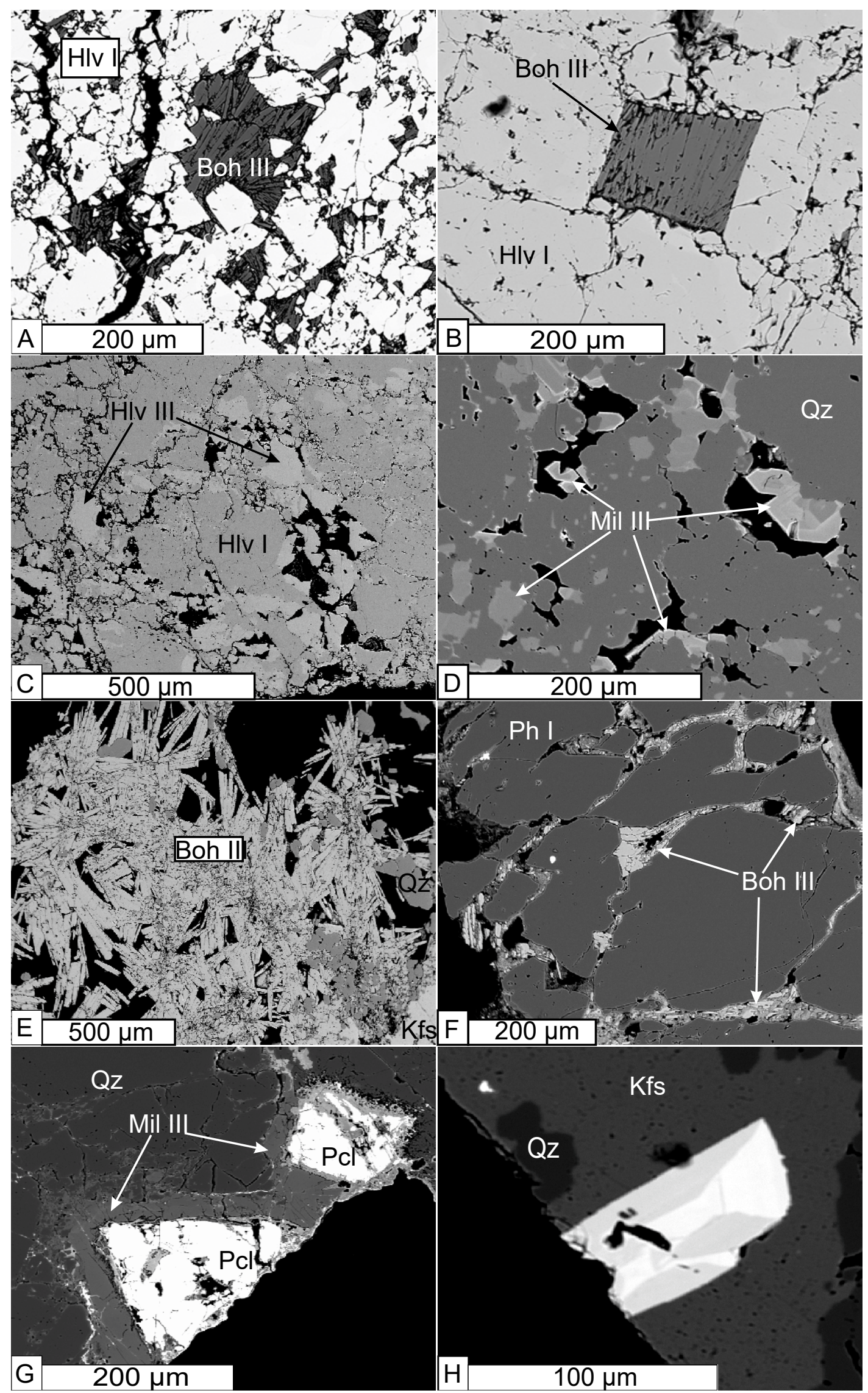




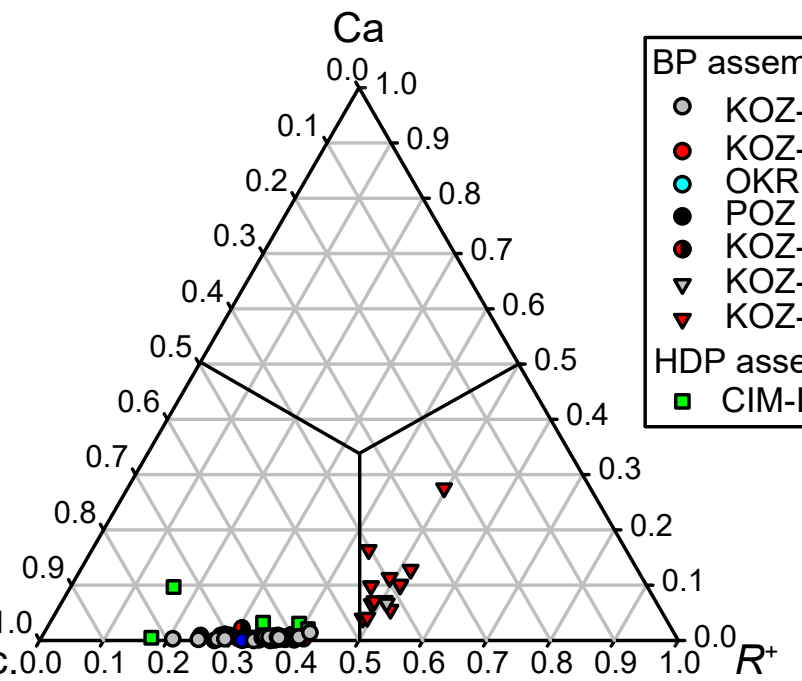

Fig. 6 Chemical variation of beryl $(\mathrm{Brl})$ and bazzite $(\mathrm{Bz})$.

very rare beryl I is typically altered to milarite III to rare agakhanovite-(Y) III (Fig. 5d) and bohseite-bavenite III (Fig. 5e). They replace, partially to almost wholly phenakite crystals. Also, they fill thin cracks in phenakite I or fill veinlets and small voids distal from phenakite. Commonly, they are associated with late-stage quartz, adularia, and locally also with axinite and rare REE-rich epidote (Fig. $5 \mathrm{f})$. $R E E$-rich milarite III to agakhanovite-(Y) III, which overgrows anhedral cubic crystals of $R E E$-rich pyrochlore s.l. (Fig. $5 \mathrm{~g}$ ), is a further paragenetic type related to the quartz+adularia assemblage. Unfrequent euhedral crystals of gadolinite-group minerals III, having less than $50 \mu \mathrm{m}$ across (Fig. 5h), are embedded in late quartz, adularia, or milarite III, as well. Textural relations indicate that formation of danalite III, milarite- and gadolinite-group minerals, and adularia + quartz preceded the formation of bohseite-bavenite series.

\subsection{Chemical composition of Be-minerals and associated tourmaline}

Beryl I and II from all studied pegmatites are chemically heterogeneous but very similar (Figs 3a,b, 6, Tab. 3), showing Al (1.45-1.74 apfu), Sc $(\leq 0.06 a p f u), \mathrm{Mg}$ (0.21-0.39 apfu), $\mathrm{Fe}_{\text {tot }}(0.03-0.14 a p f u), \mathrm{Na}(0.17-0.34$ $a p f u)$, and low concentrations of $\mathrm{K}(\leq 0.07 a p f u)$ and $\mathrm{Rb}$ $(\leq 0.01 \mathrm{apfu})$. Elevated Cs $(\leq 0.15 \mathrm{apfu})$ caused the zoning of primary beryl I in the BSE images (Figs. 3a,b). The concentrations of $\mathrm{Sc}$ increase gradually from the center to the rim, whereas Fe exhibits an opposite trend. Cesium is concentrated along with the prismatic faces, whereas the outermost terminal parts of crystals are inferior in Cs (see Fig. 3a). LA-ICP-MS data in beryl I from the Kožichovice II pegmatite yielded $\mathrm{Li} \leq 80$, Sc 477-2446, $\mathrm{Ti} \leq 89$, V 20-112, $\mathrm{Ni} \leq 38, \mathrm{Zn} \leq 48, \mathrm{Ga} \leq 40, \mathrm{Rb} 257-604$, $\mathrm{Sn} \leq 18$, Cs 2741-26973 ppm (Novák and Filip 2010).
Rare beryl I from the HDP assemblage is also enriched in $\mathrm{Na}(0.32-0.40$ apfu $), \mathrm{Fe}$ and $\mathrm{Mg}(\leq 0.11-0.28,0.21-0.28$ apfu, respectively) but Sc-free. Bazzite III shows extreme enrichment in $\mathrm{Na}(\leq 0.5$ apfu $)$ and $\mathrm{Mg}(\leq 0.6$ apfu $)$ and locally also $\mathrm{Ca}(\leq 0.3$ apfu $)$ but is Al-poor $(0.02-0.26$ $a p f u)$. An average empirical formula could be expressed as $\left(\mathrm{Na}_{0.5} \mathrm{Ca}_{0.1} \mathrm{Cs}_{0.1} \square_{0.3}\right)_{\Sigma 1.0}\left(\mathrm{Sc}_{1.1} \mathrm{Mg}_{0.5} \mathrm{Fe}_{0.2} \mathrm{Mn}_{0.1} \mathrm{Al}_{0.1}\right)_{\Sigma 2.0} \mathrm{Be}_{3} \mathrm{Si}_{6} \mathrm{O}_{18}$.

Chemical composition of all types of phenakite I, II and III is very close to the ideal formula (Tab. 3), only traces of $\mathrm{FeO}(<0.32$ wt. $\%), \mathrm{MnO}(<0.13$ wt.\%) and $\mathrm{Na}_{2} \mathrm{O}(<0.07$ wt.\%) were found.

Chemical analyses of primary helvite-danalite (Fig. 7 , Tab. 4) gave dominant Fe-rich helvite I to Mn-rich danalite I with $0.40-0.60$ of $\mathrm{Mn} /(\mathrm{Mn}+\mathrm{Fe})$, low concentrations of $\mathrm{Zn}(0.07-0.11 a p f u)$ and $\mathrm{Mg}(\leq 0.02 a p f u)$. The minor secondary Mn-rich danalite III with $0.38-0.40$ of $\mathrm{Mn} /$ $(\mathrm{Mn}+\mathrm{Fe})$ has distinctively elevated $\mathrm{Zn}(0.33-0.51 \mathrm{apfu})$.

Secondary milarite III replacing phenakite, intergrowing with adularia, or penetrating helvite-danalite usually has $\sim 1$ apfu $\mathrm{Al}$, low Fe, Mn, and Sc typically $\leq 0.1$ apfu and REE below the detection limit of EPMA; it is close to milarite s.s. On the other hand, the milarite-group min-

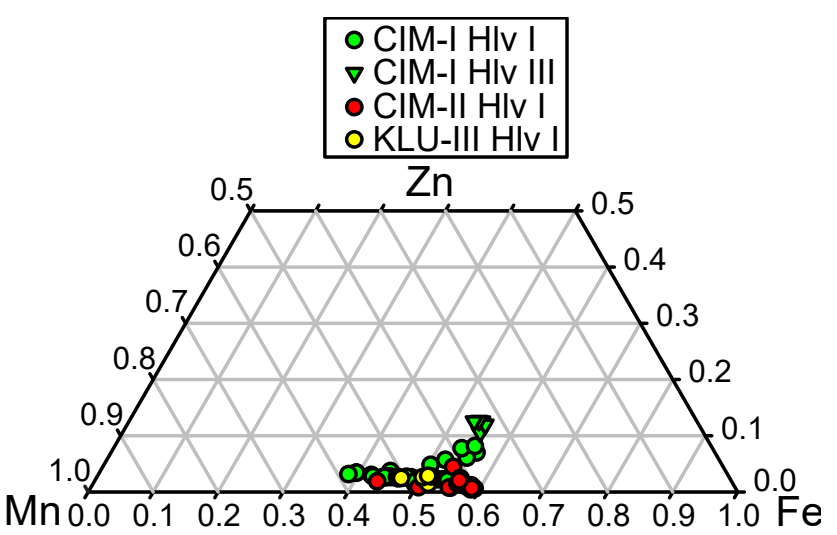

Fig. 7 Chemical composition of helvite-danalite. 
Tab. 4 Representative analyses of helvite-danalite

\begin{tabular}{|c|c|c|c|c|c|c|c|}
\hline \multirow[t]{3}{*}{ Sample } & CIM-I & CIM-I & CIM-I & CIM-II & CIM-II & KLU-III & KLU-III \\
\hline & Hlv I & Hlv I & Hlv III & Hlv I & Hlv I & Hlv I & Hlv I \\
\hline & 1 & 2 & 3 & 4 & 5 & 6 & 7 \\
\hline $\mathrm{SiO}_{2}$ & 32.78 & 33.66 & 32.66 & 32.13 & 31.94 & 32.07 & 32.67 \\
\hline $\mathrm{MgO}$ & 0.00 & 0.05 & 0.09 & 0.00 & 0.00 & 0.00 & 0.00 \\
\hline $\mathrm{CaO}$ & 0.00 & 0.00 & 0.00 & 0.00 & 0.00 & 0.00 & 0.00 \\
\hline $\mathrm{MnO}$ & 27.77 & 22.75 & 16.92 & 21.33 & 27.86 & 26.20 & 23.40 \\
\hline $\mathrm{FeO}$ & 21.54 & 26.84 & 27.95 & 30.45 & 22.52 & 24.63 & 26.63 \\
\hline $\mathrm{ZnO}$ & 1.76 & 1.31 & 7.35 & 0.63 & 1.11 & 1.48 & 1.61 \\
\hline $\mathrm{BeO}$ & 13.64 & 14.01 & 13.59 & 13.37 & 13.29 & 13.35 & 13.60 \\
\hline S & 5.19 & 5.14 & 5.10 & 5.59 & 5.89 & 5.61 & 4.92 \\
\hline $\mathrm{O}=\mathrm{S}$ & -2.59 & -2.56 & -2.54 & -2.79 & -2.94 & -2.80 & -2.46 \\
\hline Total & 100.08 & 101.19 & 101.12 & 100.72 & 99.67 & 100.54 & 100.37 \\
\hline \multicolumn{8}{|l|}{ apfu } \\
\hline $\mathrm{Si}^{4+}$ & 3.000 & 3.000 & 3.000 & 3.000 & 3.000 & 3.000 & 3.000 \\
\hline $\mathrm{Mg}^{2+}$ & 0.000 & 0.007 & 0.012 & 0.000 & 0.000 & 0.000 & 0.000 \\
\hline $\mathrm{Ca}^{2+}$ & 0.000 & 0.000 & 0.000 & 0.000 & 0.000 & 0.000 & 0.000 \\
\hline $\mathrm{Mn}^{2+}$ & 2.152 & 1.717 & 1.317 & 1.687 & 2.216 & 2.076 & 1.821 \\
\hline $\mathrm{Fe}^{2+}$ & 1.649 & 2.001 & 2.142 & 2.378 & 1.769 & 1.927 & 2.045 \\
\hline $\mathrm{Zn}^{2+}$ & 0.119 & 0.086 & 0.499 & 0.043 & 0.077 & 0.102 & 0.109 \\
\hline $\mathrm{Be}^{2+}$ & 3.000 & 3.000 & 3.000 & 3.000 & 3.000 & 3.000 & 3.000 \\
\hline $\mathrm{S}^{2-}$ & 0.889 & 0.858 & 0.877 & 0.979 & 1.038 & 0.984 & 0.847 \\
\hline $\mathrm{O}^{2-}$ & 12.031 & 11.953 & 12.093 & 12.129 & 12.024 & 12.121 & 12.128 \\
\hline \multicolumn{8}{|l|}{ mol. \% } \\
\hline dan & 42.06 & 52.69 & 54.32 & 57.88 & 43.54 & 46.94 & 51.45 \\
\hline hlv & 54.90 & 45.05 & 33.13 & 41.07 & 54.57 & 50.57 & 45.80 \\
\hline gth & 3.04 & 2.26 & 12.55 & 1.05 & 1.89 & 2.49 & 2.75 \\
\hline
\end{tabular}

dan - danalite; hlv - helvite; gth - genthelvite

eral III, closely associated with $R E E$-rich pyrochlore s.l., contains a low amount of Al (0.36-0.44 apfu) and moderate content of Y (0.39-0.47apfu), along with minor Ln $(\leq 0.1$ apfu Ln) (Electronic supplementary material, ESM 1). It suggests a transitional composition between milarite s.s., and agakhanovite-(Y) with 22-55 mol. \% of agakhanovite-(Y) component, and thus corresponds to $R E E$-rich milarite to agakhanovite-(Y).

Composition of the gadolinite-group mineral (Fig. 3f, ESM 1) is variable; the analyses yielded 0.79-1.05 apfu $\mathrm{Ca}, 0.62-0.85$ apfu Y, 0.20-0.40 apfu $\mathrm{Ln}(\mathrm{Nd}>\mathrm{Gd}>\mathrm{Sm})$, $0.46-0.48 a p f u$ of Fe and traces of $\mathrm{Mg}$ and $\mathrm{Mn}(\leq 0.02$ apfu), see Fig. 8. Such composition is challenging to be classified without direct determination of Be and B content. Common primary tourmaline, secondary tourmaline after helvite-danalite I, and hydrothermal axinite suggest high activity of B in the system, including pegmatite melt and residual fluids. Hence, we can expect the availability of B during crystallization of gadolinite-group mineral and thus, its possible entrance along with Be into the structure (Cámara et al. 2008; Bačík et al. 2017). Using the general formula of gadolinite group $A_{2} M Q_{2}\left(\mathrm{SiO}_{4}\right)_{2}(\mathrm{O}, \mathrm{OH})_{2}$, where $A=\mathrm{Ca}, R E E ; M=\mathrm{Fe}, \mathrm{Mn}, \mathrm{Mg}, \square$ and $Q=\mathrm{B}, \mathrm{Be}$ (Bačík et al. 2017). Its chemical composition falls in the center of quadrilateral diagram $R E E /(\mathrm{Ca}+R E E) v s . R^{2+}$ $\left(\mathrm{R}^{2+}+\right.$ vacancy) and thus corresponds to an intermedi- ate composition of either hingganite-(Y)-homilite or gadolinite-(Y)-datolite solid solutions. Keeping the nomenclature formalism for the gadolinite-group minerals (Bačík et al. 2017), domains brighter in BSE fall to the $\mathrm{Ca}-$, and Fe-rich hingganite-(Y) compositional field and the darker domains correspond to $\square$-, and REE-rich homilite. The calculated content of Be and B are 0.95-1.21 and 0.79-1.05 apfu, respectively (ESM 1).

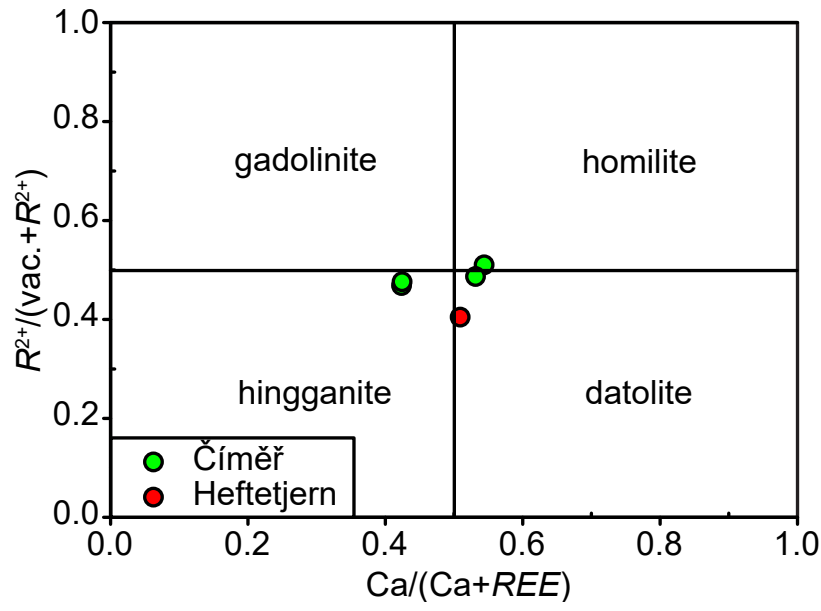

Fig. 8 Chemical composition of gadolinite-group mineral from Číměř I (this study) and Heftetjern pegmatites (Cooper et al. 2019). 
Tab. 5 Representative analyses of minerals of bavenite-bohseite series

\begin{tabular}{|c|c|c|c|c|c|c|}
\hline Precursor & Brl I & Brl I & Hlv I & Hlv I & Phk I & Phk I \\
\hline \multirow{2}{*}{ Locality } & KOZ-II & KOZ II & CIM-I & CIM-I & CIM-I & KLU-III \\
\hline & 1 & 2 & 3 & 4 & 5 & 6 \\
\hline $\mathrm{SiO}_{2}$ & 58.60 & 57.78 & 58.82 & 59.35 & 59.48 & 58.88 \\
\hline $\mathrm{Al}_{2} \mathrm{O}_{3}$ & 4.80 & 4.09 & 1.93 & 5.48 & 2.50 & 0.85 \\
\hline $\mathrm{CaO}$ & 23.81 & 23.68 & 24.07 & 24.17 & 24.58 & 25.16 \\
\hline $\mathrm{MnO}$ & 0.06 & 0.04 & 0.35 & 0.00 & 0.00 & 0.11 \\
\hline $\mathrm{FeO}$ & 0.00 & 0.03 & 0.26 & 0.00 & 0.00 & 0.00 \\
\hline $\mathrm{Na}_{2} \mathrm{O}$ & 0.28 & 0.26 & 0.16 & 0.11 & 0.11 & 0.12 \\
\hline $\mathrm{F}$ & 0.22 & 0.25 & 0.20 & 0.20 & 0.22 & 0.54 \\
\hline$* \mathrm{BeO}$ & 8.48 & 8.68 & 9.93 & 8.29 & 9.77 & 10.48 \\
\hline$* * \mathrm{H}_{2} \mathrm{O}$ & 3.01 & 3.01 & 3.38 & 3.00 & 3.41 & 3.22 \\
\hline $\mathrm{O}=\mathrm{F}$ & -0.09 & -0.11 & -0.08 & -0.09 & -0.09 & -0.23 \\
\hline Total & 99.18 & 97.71 & 99.02 & 100.52 & 99.98 & 99.13 \\
\hline \multicolumn{7}{|l|}{ apfu } \\
\hline $\mathrm{Si}^{4+}$ & 9.000 & 9.000 & 9.000 & 9.000 & 9.000 & 9.000 \\
\hline $\mathrm{Al}^{3+}$ & 0.869 & 0.751 & 0.349 & 0.979 & 0.446 & 0.153 \\
\hline $\mathrm{Ca}^{2+}$ & 3.919 & 3.952 & 3.946 & 3.928 & 3.985 & 4.121 \\
\hline $\mathrm{Mn}^{2+}$ & 0.008 & 0.005 & 0.045 & 0.000 & 0.000 & 0.015 \\
\hline $\mathrm{Fe}^{2+}$ & 0.000 & 0.004 & 0.033 & 0.000 & 0.000 & 0.000 \\
\hline $\mathrm{Na}^{+}$ & 0.085 & 0.079 & 0.049 & 0.033 & 0.033 & 0.035 \\
\hline $\mathrm{F}^{-}$ & 0.109 & 0.123 & 0.097 & 0.097 & 0.104 & 0.260 \\
\hline $\mathrm{Be}^{2+}$ & 3.131 & 3.249 & 3.651 & 3.021 & 3.554 & 3.847 \\
\hline $\mathrm{OH}^{-}$ & 3.084 & 3.125 & 3.457 & 3.035 & 3.447 & 3.281 \\
\hline $\mathrm{O}^{2-}$ & 24.807 & 26.376 & 24.446 & 24.868 & 24.449 & 24.459 \\
\hline
\end{tabular}

* calculated from stoichiometry

** calculated from charge balance

Minerals of bavenite-bohseite series have the general formula $\mathrm{Ca}_{4} \mathrm{Be}_{2+x} \mathrm{Al}_{2-x} \mathrm{Si}_{9} \mathrm{O}_{28-x}(\mathrm{OH})_{2+x}$, where $x<1$ for bavenite and $x>1$ for bohseite (Friis et al. 2010). Their chemical composition from the studied pegmatites is highly variable (Tab. 5). Bavenite to Al-rich bohseite is related to replacement of beryl I (BP assemblage) and contain 0.75-1.13 apfu Al (4.09-5.85 wt. \% $\mathrm{Al}_{2} \mathrm{O}_{3}$ ) (Fig. 9). In the HDP assemblage, the minerals of bohseite-bavenite series after helvite-danalite I shows 0.36-1.05 apfu $\mathrm{Al}\left(1.93-5.48\right.$ wt. $\% \mathrm{Al}_{2} \mathrm{O}_{3}$ ) and en-

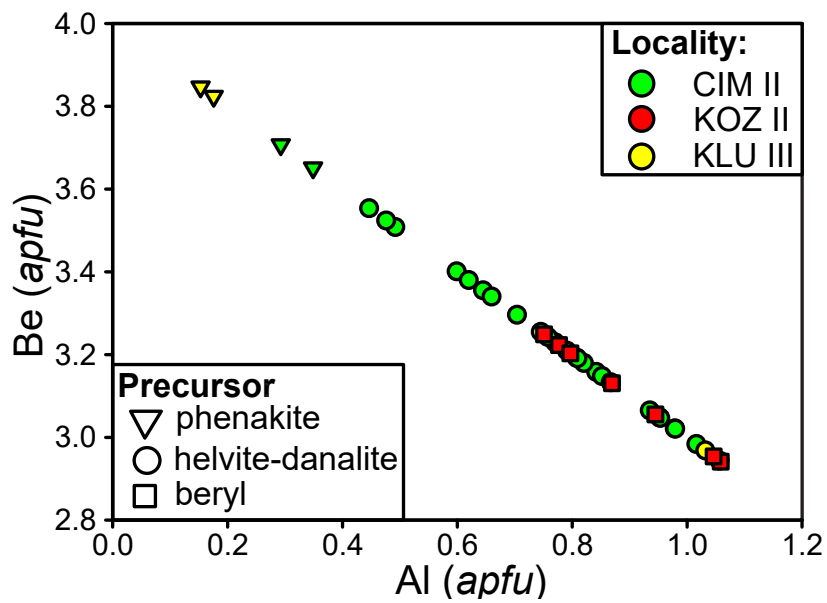

Fig. 9 Variation of Al-content in bavenite-bohseite series reflecting the variable amount of $\mathrm{Al}$ in their precursor. richment in $\mathrm{Fe}$ and $\mathrm{Mn}(\leq 0.1$ $a p f u$ ). Fissures-filling bohseite III related to phenakite I alteration has very low $\mathrm{Al}(0.16-0.77$ apfu; 0.85-4.34 wt. \% $\mathrm{Al}_{2} \mathrm{O}_{3}$ ), and elevated $\mathrm{F}(\leq 0.3 a p f u)$. Rare bohseite-bavenite after milarite I provided 0.82-1.02 apfu $\mathrm{Al}$ (4.14-5.67 wt. \% $\mathrm{Al}_{2} \mathrm{O}_{3}$ ).

Typical features of tourmaline from the Třebíč Pluton euxenite-type pegmatites is their low Al content ( 5-6.4 apfu) and mostly low vacancy in the $X$-site (Novák et al. 2011). Tourmalines (schorl-dravite) from beryl and helvite-danalite pegmatites show low Al 5-6 $a p f u$ and variable $\mathrm{Fe} /(\mathrm{Fe}+\mathrm{Mg})$ $=0.28-0.96$ higher in the latter (Fig. 10, Tab. 6). In beryl pegmatites, scarce tourmaline occurs in the outer pegmatite unit, or it is a late fracture-filling type (see Novák et al. 2011) whereas in helvite-danalite pegmatites abundant tourmaline crystallized from outer to central pegmatite units.

\section{Discussion}

\subsection{Chemical composition of Be-minerals}

Data on chemical composition of beryl from NYF pegmatites are rather scarce (e.g., Aurisicchio et al. 1988; Novák and Filip 2010; Přikryl et al. 2014), compared to e.g., LCT pegmatites (Černý et al. 2003; Wang et al. 2009; Uher et al. 2010, 2017; Aurisicchio et al. 2012). Chemical composition of primary beryl I and II from all examined localities of euxenite-type pegmatites in the Třebíč Pluton (Tab. 3, Fig. 6) are very similar. It is also in line with the composition of beryl from the Kožichovice II pegmatite (Tab. 1) studied in detail by Novák and Filip (2010). Beryl from the Třebíč pegmatites is Mg-rich (Mg $>\mathrm{Fe}$ ) and high contents of $\mathrm{Mg}, \mathrm{Sc}$ and Cs reflect the high concentrations of these elements in parental durbachite of the Třebíč Pluton (Novák et al. 2012). Moreover, it also reflects their concentrations in the residual melt from which the pegmatites formed. Substantial octahedral substitution is indicated by rather low $\mathrm{Al}$ and elevated $R^{2+}$, and the charge is balanced by entering of $R^{+}$into channels (Fig. 6). Not only the high contents of Mg in beryl, but also in other minerals (tourmaline, biotite) from Třebíč 


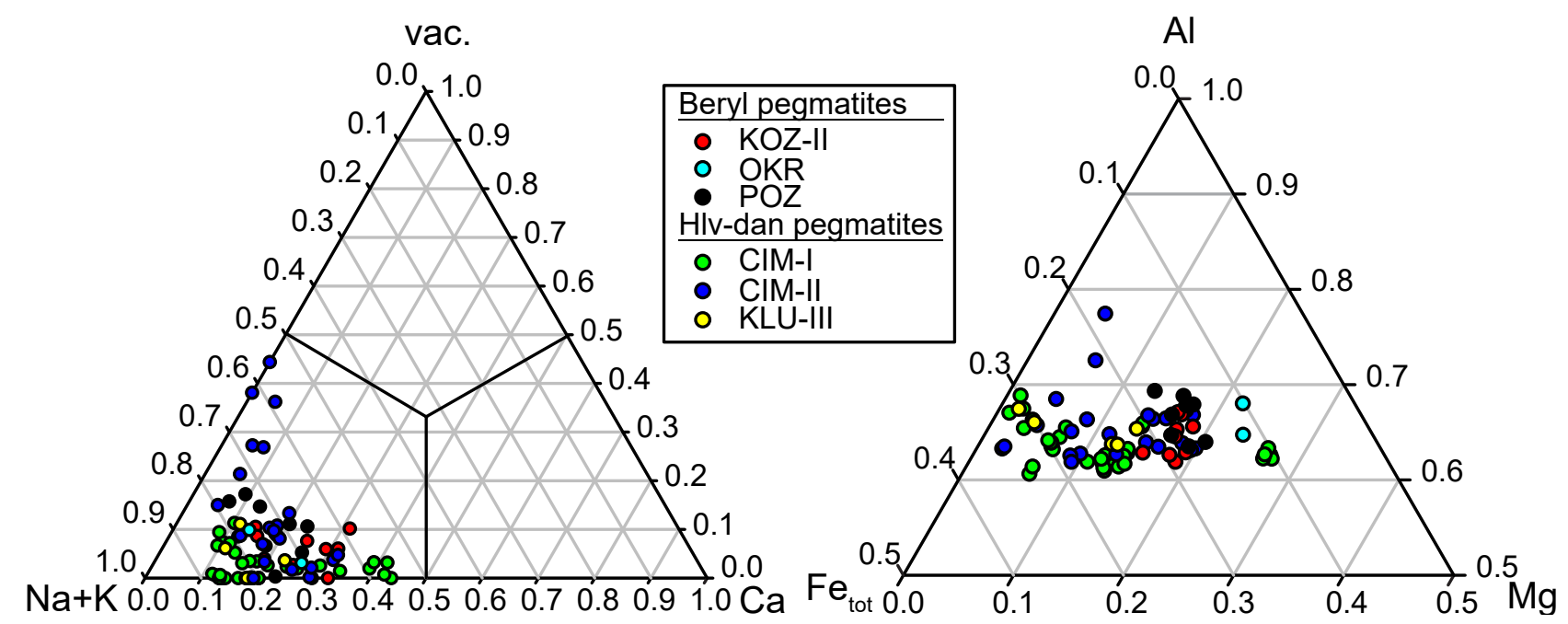

Fig. 10 Chemical composition of tourmaline from TP euxenite-subtype pegmatites.

Tab. 6 Chemical composition of tourmaline from euxenite-subtype pegmatites of the Třebič Pluton

\begin{tabular}{|c|c|c|c|c|c|c|c|}
\hline & \multicolumn{3}{|c|}{ Beryl-bearing pegmatites } & \multicolumn{4}{|c|}{ Helvite-bearing pegmatites } \\
\hline & KOZ-II & $\mathrm{POZ}$ & OKR & CIM-I & CIM-I & CIM-II & KLU-III \\
\hline & 1 & 2 & $3^{\#}$ & 4 & 5 & 6 & 7 \\
\hline $\mathrm{SiO}_{2}$ & 35.48 & 36.51 & 35.69 & 34.14 & 34.58 & 34.50 & 35.47 \\
\hline $\mathrm{TiO}_{2}$ & 3.01 & 0.33 & 2.71 & 4.06 & 1.16 & 2.74 & 3.65 \\
\hline $\mathrm{Al}_{2} \mathrm{O}_{3}$ & 26.31 & 30.66 & 26.24 & 25.49 & 28.25 & 25.68 & 26.64 \\
\hline${ }^{\dagger} \mathrm{Fe}_{2} \mathrm{O}_{3}$ & 2.94 & 2.64 & 1.95 & 4.41 & 3.40 & 4.68 & 3.88 \\
\hline $\mathrm{MgO}$ & 6.35 & 5.65 & 7.81 & 3.50 & 4.68 & 3.06 & 4.17 \\
\hline $\mathrm{CaO}$ & 1.80 & 0.74 & 1.97 & 0.88 & 0.66 & 0.33 & 1.01 \\
\hline $\mathrm{MnO}$ & 0.34 & 0.13 & 0.15 & 0.32 & 0.21 & 0.51 & 0.37 \\
\hline $\mathrm{FeO}_{\mathrm{tot}}$ & 7.63 & 6.87 & 7.03 & 11.45 & 8.84 & 12.16 & 10.09 \\
\hline $\mathrm{Na}_{2} \mathrm{O}$ & 2.01 & 2.24 & 1.94 & 2.40 & 2.32 & 2.13 & 2.46 \\
\hline $\mathrm{K}_{2} \mathrm{O}$ & 0.08 & 0.05 & 0.05 & 0.08 & 0.04 & 0.03 & 0.10 \\
\hline$* \mathrm{~B}_{2} \mathrm{O}_{3}$ & 10.28 & 10.58 & 10.34 & 9.89 & 10.01 & 9.99 & 10.27 \\
\hline$* \mathrm{H}_{2} \mathrm{O}$ & 3.20 & 3.83 & 3.42 & 2.13 & 2.92 & 2.97 & 2.87 \\
\hline $\mathrm{F}$ & 0.22 & 0.17 & 0.25 & 0.31 & 0.29 & 0.42 & 0.21 \\
\hline$-\mathrm{O}=\mathrm{F}$ & -0.11 & -0.09 & -0.11 & -0.16 & -0.15 & -0.22 & -0.10 \\
\hline Total & 99.54 & 100.31 & 99.44 & 98.90 & 97.21 & 98.97 & 101.09 \\
\hline \multicolumn{8}{|l|}{ apfu } \\
\hline $\mathrm{Si}^{4+}$ & 6.000 & 6.000 & 6.000 & 6.000 & 6.000 & 6.000 & 6.000 \\
\hline $\mathrm{Ti}^{4^{++}}$ & 0.383 & 0.041 & 0.342 & 0.537 & 0.152 & 0.358 & 0.464 \\
\hline $\mathrm{Al}^{3+}$ & 5.247 & 5.939 & 5.200 & 5.281 & 5.779 & 5.264 & 5.312 \\
\hline $\mathrm{Fe}^{3+}$ & 0.374 & 0.327 & 0.247 & 0.583 & 0.444 & 0.612 & 0.494 \\
\hline $\mathrm{Mg}^{2+}$ & 1.602 & 1.384 & 1.957 & 0.918 & 1.209 & 0.792 & 1.051 \\
\hline $\mathrm{Ca}^{2+}$ & 0.326 & 0.131 & 0.356 & 0.166 & 0.123 & 0.062 & 0.183 \\
\hline $\mathrm{Mn}^{2+}$ & 0.049 & 0.018 & 0.021 & 0.047 & 0.031 & 0.075 & 0.053 \\
\hline $\mathrm{Fe}^{2+}$ & 1.121 & 0.981 & 0.988 & 1.749 & 1.332 & 1.836 & 1.482 \\
\hline $\mathrm{Na}^{+}$ & 0.659 & 0.713 & 0.632 & 0.818 & 0.782 & 0.718 & 0.807 \\
\hline $\mathrm{K}^{+}$ & 0.017 & 0.010 & 0.012 & 0.017 & 0.009 & 0.006 & 0.022 \\
\hline $\mathrm{B}^{3+}$ & 3.000 & 3.000 & 3.000 & 3.000 & 3.000 & 3.000 & 3.000 \\
\hline $\mathrm{OH}^{-}$ & 3.611 & 3.912 & 3.830 & 2.498 & 3.381 & 3.449 & 3.243 \\
\hline $\mathrm{F}^{-}$ & 0.117 & 0.088 & 0.135 & 0.172 & 0.161 & 0.232 & 0.110 \\
\hline $\mathrm{O}^{2-}$ & 27.272 & 27.000 & 27.035 & 28.330 & 27.458 & 27.319 & 27.647 \\
\hline
\end{tabular}


pegmatites, make them distinct from typical NYF pegmatites. Therefore those, where beryl is rich in $\mathrm{Fe}(\mathrm{Fe}>$ $\mathrm{Mg}$ ) (Aurisicchio et al. 1988; Přikryl et al. 2014) as other Fe,Mn,Mg-minerals (Falster et al. 2012, 2018). Bazzite III shows extreme enrichment in $\mathrm{Na}(\leq 0.5$ apfu $), \mathrm{Mg}$ $(\leq 0.6$ apfu $)$ and $\mathrm{Fe}(\leq 0.2$ apfu $)$ and locally also $\mathrm{Ca}(\leq 0.3$ apfu). Part of the most Na-, Mg-, and Fe-rich analyses reaches the compositional field of a possible new mineral species of the beryl group (Fig. 6) with a general formula $A^{+} \mathrm{Sc}_{1} M^{2+}{ }_{1} \mathrm{Be}_{3} \mathrm{Si}_{6} \mathrm{O}_{18}$.

Helvite-group minerals from NYF pegmatites of Třebíč Pluton include Fe-rich helvite I to Mn-rich danalite $\mathrm{I}, \mathrm{Mn} /(\mathrm{Mn}+\mathrm{Fe})=0.4-0.6$, and locally, secondary Mn-rich danalite III enriched in Zn $(\leq 0.51$ apfu $)$ with $\mathrm{Mn} /(\mathrm{Mn}+\mathrm{Fe}) \sim 0.4$. Despite an abundance of $\mathrm{Mg}$ in the pegmatite melt, its concentration in helvite is very low (Tab. 4). Such low Mg content is typical for all helvitegroup minerals reported in the literature (e.g., Dunn 1976; Barton and Young 2002) and thus an entrance of Mg to the helvite-danalite structure is controlled by crystalstructural constrains. At the Třebíč pegmatites, elevated $\mathrm{Mn}$ and a very low $\mathrm{Mg}$ in magmatic helvite-group minerals are in contrast with the overall composition of mafic minerals from the examined pegmatites. Tourmaline is a dominant primary mafic mineral in helvite-danalite pegmatites, and its composition (Fig. 10, Tab. 6) reflects high compatibility of $\mathrm{Mg}$ and incompatibility of $\mathrm{Mn}$ with the tourmaline structure (Henry et al. 2011). Crystallization of large portions of tourmaline resulted in enrichment of the ongoing melt in $\mathrm{Mn}$, which facilitated the formation of helvite to Mn-rich danalite. Despite this, the chemical composition of primary helvite-group minerals differs from most granitic pegmatites where Fe-poor helvite (e.g., Barton and Young 2002; Černý 2002) and locally Zn-rich to genthelvite (Glass and Adams 1953; Zito and Hanson 2017; Larsen 1988) are typical.

The mineral of milarite group (Fig. $5 \mathrm{~g}$ ) with low Al (0.36-0.44 apfu) and moderate Y (0.39-0.47 apfu) along with minor amounts of $\operatorname{Ln}(\leq 0.1$ apfu $)$ (ESM 1$)$ is transitional between agakhanovite-(Y) and milarite s.s. The similar composition was found in late milarite from NYF pegmatite Velká skála, Písek (see Novák et al. 2017 for details) where rather high $\mathrm{Y}$ and low $\mathrm{Al}$ are typical. Secondary milarite III after helvite-danalite or phenakite with $\mathrm{Al} \sim 1$ apfu, low Fe, Mn and $\mathrm{Sc} \leq 0.1$ apfu and REE-free is similar to secondary milarite from granitic pegmatites (Černý 2002) but also to primary milarite I from the Velká skála pegmatite (Novák et al. 2017). Agakhanovite(Y) from the type locality Heftetjern, Norway, fills small miarolitic cavities as a product of late hydrothermal solutions (Hawthorne et al. 2014). Hence, the chemical composition of milarite-group minerals, in particular, reflects local enrichment of some elements than its paragenetic position within certain granitic pegmatite.
Chemical composition of gadolinite-group minerals falls to an intermediate composition among gadolinite(Y), hingganite-(Y), datolite, and homilite (see ESM 1) showing roughly half occupancy of M-site and amounts of $\sim 0.5 \mathrm{Ca} /(\mathrm{Ca}+R E E)$. Calcium-rich hingganite-(Y) with a chemical composition close to those from Číměr I is reported by Cooper et al. (2019) from Heftetjern granitic pegmatite, Norway, where it forms small crystals of hydrothermal origin the late-stage vugs. Such compositions are far from typical, early magmatic gadolinite known from granitic pegmatites Baveno, Italy (Pezzotta et al. 1999), Ytterby, Sweden (Smeds 1990), White Cloud, Colorado (Henry 2013) where A-site is predominantly occupied by HREE, $\mathrm{Fe}$ is dominating over $\square$ and $\mathrm{Be}>$ B. Consequently, an elevated $M$-site vacancy could be considered as an indicator of the hydrothermal origin of gadolinite-group minerals in granitic systems and the compositional shift towards datolite gives evidence for elevated $\mathrm{Ca}$ and $\mathrm{B}$ activity. The chemistry roughly corresponds to an insufficiently described mineral calcybeborsilite (see Rastsvetaeva et al. 1996) from the boronrich alkaline pegmatite Dara-i-Pioz, Tajikistan where it seems to be of a magmatic origin (Pekov et al. 2000). The chemical composition of bohseite-bavenite series is highly variable with high $\mathrm{Al}(0.75-1.06 a p f u)$ in replacement products of beryl I and milarite I and moderate to low Al (0.16-1.05 apfu) in bohseite filling fractures in helvite-danalite I and particularly after phenakite I. Such a high variability and particularly dominance of bohseite after bavenite is unusual (Szełęg et al. 2017). Regarding Al-contents, they decrease from Al-rich, beryl-hosted to Al-poor, phenakite-hosted environments (Zachař and Škoda 2019).

\subsection{Paragenetic position of primary Be-minerals and mineral replacement reactions}

Beryllium-minerals as euhedral to subhedral crystals and their aggregates enclosed in a massive pegmatite (beryl I, phenakite I, and helvite-danalite I) crystallized at the primary (magmatic) stage. Similar morphologies and mineral assemblages are known from elsewhere (London 2008). High variability in primary Be-minerals, including beryl, phenakite, and helvite-danalite is reflected in the mineral assemblages of secondary Be-minerals and their chemical composition. The following replacement paths were observed:

1) beryl I $\rightarrow$ bohseite-bavenite III + beryl III

+ bazzite III + smectite (Novák and Filip 2010)

2) beryl I $\rightarrow$ bohseite-bavenite III + clinozoisite

3) beryl I $\rightarrow$ phenakite III + K-feldspar + jarosite

4) phenakite I $\rightarrow$ milarite III

5) phenakite I $\rightarrow$ bohseite III 
6) helvite-danalite I $\rightarrow$ helvite-danalite III

7) helvite-danalite I $\rightarrow$ bohseite III \pm ferroor mangan-axinite

Alterations of beryl I (reactions 1-3) are limited to the BP assemblage. Reaction 1) and 2) are typical for the Kožichovice II pegmatite, whereas path 3) was observed exclusively in the Okrašovice pegmatite. The sequence of crystallization of secondary Be-minerals is not easy to define in most examined samples. Beryl III from late veinlets in beryl I (Fig. 4b) is likely the earliest among the secondary minerals, whereas bohseite-bavenite is mostly the latest mineral. Phenakite I is resistant to any alteration in the BP assemblage. Reactions 4-7) are restricted to the HDP assemblage. Phenakite replacements reactions 4) and 5) could take place at the same hand samples and reaction 4) preceded reaction 5). Helvite-danalite I is commonly altered to bohseite III (reaction 7) or rarely to helvite-danalite III (reaction 6). These reactions were spatially and genetically separated, and textural features indicate that the formation of danalite III was a highertemperature event compared to the formation of bohseite III (Fig. 5a, b). No replacements of earlier secondary Be-minerals by later ones were observed either in beryl or helvite-danalite pegmatites.

\subsection{Geochemical conditions during the origin of primary and secondary Be-minerals in granitic pegmatites}

Activity and P-T diagrams published by Barton (1986), Barton and Young (2002), Franz and Morteani (2002) and Markl (2001) illustrate that activities of Si and Al and alkalinity/acidity are crucial for the stability of Beminerals along with activities of $\mathrm{Fe}, \mathrm{Mg}, \mathrm{Mn}, R E E, \mathrm{P}, \mathrm{B}$, $\mathrm{S}$, and $f_{\mathrm{O} 2}$; consequently, geochemical potentials govern the stability of Be-minerals in particular along with PT conditions.

Primary Be-minerals may be used for elucidation of activities of elements and fluids in single pegmatites or within the individual pegmatite units. The by far most abundant pegmatites with beryl as a sole primary Bemineral reflect its large stability field (Barton 1986; Franz and Morteani 2002) but also peraluminous nature of most granitic pegmatites of the rare-element class (e.g., London 2008; Černý et al. 2012). Strongly peraluminous pegmatites also contain sole chrysoberyl or the assemblage beryl + chrysoberyl (London 2008). The Třebíč Pluton pegmatites with beryl ( \pm phenakite) as a sole primary Be-mineral (Tab. 1) are only slightly peraluminous, where Al-rich minerals (e.g., muscovite, garnet, cordierite, andalusite) are absent and rare tourmaline has $\mathrm{Al}_{\text {tot }}<6$ apfu (Fig. 10; Novák et al. 2011; Čopjaková et al. 2013). Thus, it may represent an Al-poor variety of aforementioned peraluminous pegmatites. Berylliumbearing granitic pegmatites depleted in Al (slightly peraluminous or metaluminous in composition) are less common worldwide and the assemblage phenakite + beryl or dominant phenakite are typical (e.g., Falster et al. 2012, 2018). Only the pegmatite Kožichovice II (Novák and Filip 2010) is close to this type (Tab. 1).

If activities of some other cations are sufficiently high and activity of $\mathrm{Al}$ appropriately low, we can find primary helvite-group minerals ( $\mathrm{Mn}, \mathrm{Fe}$, low $f_{\mathrm{O} 2}$ ), milarite-group minerals $(\mathrm{Ca}, \mathrm{K}, R E E)$ and/or gadolinite-group minerals $(R E E, \mathrm{Fe})$. The helvite-danalite pegmatites locally with rare primary phenakite, milarite- and gadolinite-group mineral from Číměř I, II and Klučov III (Tab. 1) are examples of these metaluminous pegmatites with common Al-poor tourmaline (Fig. 10), where also low $f_{\mathrm{O} 2}$ is evident from the abundance of sulfides (Tab. 1).

High activity of $P$, typically found in strongly peraluminous pegmatites, with contemporary elevated Be is indicated by the presence of primary hurlbutite along with common apatite (Černý 2002); however, very low contents of $\mathrm{P}$ in the Třebíč pegmatites manifested also by low $\mathrm{P}$ in feldspars, and almost total absence of phosphates (Škoda et al. 2006) follow their metaluminous character.

High B in pegmatites promoted the formation of hambergite and/or rhodizite-group minerals (London 2008) along with abundant Al-rich tourmaline, all typically associated with beryl (e.g., Novák et al. 2015). Such conditions were found in the Kracovice pegmatite. However, primary beryl has not been found at this pegmatite, and origin of borates from melt requires elevated alkalinity (e.g., Novák and Povondra 1995; Novák et al. 1998; London 2005, 2008).

Secondary Be-minerals show distinct mineral assemblages in beryl pegmatites (BP assemblage) and helvite-danalite pegmatites (HDP assemblage). Variable contents of $\mathrm{Al}$ in primary Be-minerals are manifested very well in the secondary mineral assemblages. Chemical composition of bohseite-bavenite III reflects Al-contents of its precursor: after beryl I (0.75-1.06 Al $a p f u)$, after helvite-danalite I (0.35-0.98 Al apfu) and after phenakite I (0.16-0.75 Al apfu). The dominance of minerals of bohseite-bavenite series over other secondary Be-minerals along with secondary milarite, also shows high activity of $\mathrm{Ca}$ in hydrothermal fluids also indicated by late axinite-( $\mathrm{Fe}, \mathrm{Mn})$, epidote-clinozoisite, and titanite (Škoda et al. 2006; Novák and Filip 2010) as well as neutral to alkaline conditions (Černý 2002). These fluids were likely exsolved from pegmatite residual melt with the negligible role of external fluids derived from host durbachite. It is manifested by the absence or very low contents of $\mathrm{Mg}$ in most secondary Be-minerals (see Novák et al. 2017) except for bazzite III where $\mathrm{Mg}$ is likely sourced from altered primary 
Mg-enriched beryl I (Tab. 3). Variations in the chemical composition of bohseite-bavenite are controlled by the chemical composition of the precursor; Al-rich minerals of bohseite-bavenite series formed after beryl whereas Al-poor bohseite after phenakite. Aluminium content in the fluids exsolved from melt, likely rather low (Buřival and Novák 2018), was exhausted by formation Al-bearing minerals (beryl III, adularia, axinite, epidote, clinozoisite, milarite) in early stages of hydrothermal replacements. Its low mobility and negligible role during the bohseitebavenite formation is very likely. Hence, the chemical composition of minerals of bohseite-bavenite series mirrors the chemical compositions of the replaced primary phases in the local environment and shows low Al mobility at such conditions (Zachař and Škoda 2019).

\subsection{Assemblages of primary beryllium-minerals from NYF pegmatites}

Beryllium-minerals are known from several NYF intragranitic pegmatites of durbachite plutons in the Moldanubian Zone: Třebíč Pluton, Western Moravia (Škoda et al. 2006; Novák and Filip 2010), Mehelník Massif, Central Bohemia (Novák et al. 2017) and Milevsko Pluton, Central Bohemia (Škoda et al. 2004; J. Cícha pers. comm.) and display high variability. They show the evolution from relatively Al-rich assemblages in pegmatites with common beryl and locally rare phenakite to Aldepleted assemblages in pegmatites with helvite-danalite, phenakite, and very rare beryl. Two distinct trends in Al-depleted assemblages are apparent. The assemblage with dominant helvite-danalite \pm minor phenakite is characterized by high activities of $R^{2+}$ cations ( $\mathrm{Fe}, \mathrm{Mn}, \mathrm{Mg}$ ) indicated along with common helvite-danalite by abundant tourmaline. In contrast, the Velká Skála pegmatite in the Mehelník Massif, with primary milarite is highly leucocratic with rare biotite and tourmaline (Novák et al. 2017) which demonstrate low activities of $\mathrm{Mg}$ and $\mathrm{Fe}^{2+}$.

The assemblages of primary Be-minerals from the pegmatites of the Třebíć Pluton (Tabs 1,2) show quite a high variability comparing other granitic pegmatites both NYF and LCT affiliated. The most abundant primary Bemineral in NYF pegmatites is beryl (Černý 2002; Černý and Ercit 2005). It is locally associated with phenakite (as e.g., in Erongo, Namibia; Falster et al. 2018), or a scarce phenakite is dominant primary Be-mineral along with very rare beryl (as in Nine Mile Pluton, Wausau, Wisconsin; Falster et al. 2012), or it is a sole Be mineral at the locality (as in Tangen, Kragerø, Norway; Bjørlykke 1937). Helvite-group minerals scarcely occur in LCT and NYF pegmatites, the most frequently as a latestage mineral in the vugs and less commonly as primary magmatic or metasomatic phases. In general, helvite is probably the most common, whereas genthelvite seems to be less abundant. (Dunn 1976; Barton and Young 2002). Helvite-danalite from the Třebíc Pluton with Fe/ $\mathrm{Mn}$ close to 1 is rather unusual. Gadolinite-group minerals are further common primary Be-minerals in NYF pegmatites occurring with beryl at some pegmatites (e.g., Baveno, Italy, Pezzotta et al. 1999; some pegmatites at Evje-Iveland, Norway, Bjørlykke 1935; Müller et al. 2017; Høydalen, Norway, Chukanov et al. 2017; Ytterby, Sweden, Simmons 2005) but it is often the only and a rather common primary Be-mineral typically associated with some of following minerals: fluorite, magnetite, allanite, $R E E-\mathrm{Nb}-\mathrm{Ta}-\mathrm{Ti}$ oxides, and vice-versa (e.g., White Cloud, Colorado, Simmons et al. 1987; Arvogno, Alps, Guastoni et al. 2014, 2019; some pegmatites at Evje-Iveland, Norway, Bjørlykke 1935; Åskagen, Sweden, Škoda et al. 2012; Reunavare, Sweden, Škoda et al. 2015). Primary milarite in granitic pegmatites is known only from a single locality of the NYF pegmatite at Velká Skála near Písek; however, due to the similar appearance of milarite with beryl it may be easily overlooked (Novák et al. 2017).

The mineral assemblages of primary Be-minerals (beryl, phenakite, helvite-danalite) plus secondary or hydrothermal phases (beryl, bazzite, phenakite, danalite, milarite- and gadolinite-group minerals and bohseitebavenite) in a single pegmatite district (Třebíč Pluton) are unusual. Hanson and Zito (2019) described similar assemblage (bazzite, helvite-group minerals, phenakite, bertrandite, and gadolinite-group minerals) from the Mount Rosa Complex, Colorado Front Range, Colorado. However, host rocks of Be-minerals include along with variable miarolitic pegmatites, also quartz dikes, and almost all Be-minerals occur in open vugs, and their primary origin is not documented sufficiently. The system is also F-rich and differs significantly from F-poor euxenite-type pegmatites of the Třebič Pluton. Disregarding similar mineral assemblages of Be-minerals at the Mount Rosa region (Hanson and Zito 2019), they are mostly hydrothermal, whereas similar primary hydrothermal Beminerals from pockets in pegmatites of the Třebíc Pluton (beryl II, phenakite II, see Tab. 1) are very rare.

\section{Conclusions}

Beryl and helvite-danalite, major primary Be-minerals in the euxenite-type pegmatites of Třebíč Pluton, were only exceptionally found within a single pegmatite dike. It suggests different activities of $\mathrm{Al}$ in the parental medium (beryl - high, helvite-danalite - low). Abundant tourmaline in pegmatites with helvite-danalite and its scarcity in beryl pegmatites indicate that tourmaline crystallization may have controlled the formation of a primary Be-mineral. Such diverse assemblage of primary Be-minerals, 
including beryl, helvite-danalite, and phenakite within a single pegmatite district, is noteworthy.

Secondary Be-minerals with predominating bohseitebavenite series members and a minor secondary milariteand gadolinite group mineral indicate a high activity of $\mathrm{Ca}$ in fluids. Variations in the chemical composition of minerals of bohseite-bavenite series mirrors the chemical compositions of the replaced primary phases in the local environment and shows low Al mobility at such conditions.

The assemblages of primary and secondary Be-minerals from pegmatites of the Třebíc Pluton manifest that the individual assemblages are constrained by variable activities of $\mathrm{Si}$ and mainly $\mathrm{Al}$, divalent cations $-\mathrm{Ca}, \mathrm{Mn}, \mathrm{Fe}$, $\mathrm{Zn}$ and $\mathrm{Mg}$, and trivalent cations $-R E E, \mathrm{Sc} ; \mathrm{B}, \mathrm{S}$ and also $f_{\mathrm{O} 2}$ played a significant role in the formation of helvitegroup minerals (Barton and Young 2002; Franz and Morteani 2002). However, the individual primary Be-minerals are not indicative of the explicit geochemical family of granitic pegmatites except for gadolinite s.s. (NYF) and rhodizite, hurlbutite, and beryllonite (all LCT).

Acknowledgments The authors thank E. Szełęg and A. Guastoni for constructive criticism that significantly improved the manuscript and J. Plášil and J. Sejkora for excellent editorial handling. The authors also thank and V. Hrazdil and S. Houzar from the Moravian Museum, Brno, for the samples of beryl from Pozd'átky II, phenakite from Terůvky and helpful comments. This work was supported by the research project GAČR P210/19/05198S to MN and RŠ.

Electronic supplementary material. Supplementary table containing analyses of milarite- and gadolinite-group minerals is available online at the Journal web site (http:// dx.doi.org/10.3190/jgeosci.307).

\section{References}

Aurisicchio C, Fioravanti G, Grubessi O, Zanazzi PF (1988) Reappraisal of the crystal chemistry of beryl. Amer Miner 73: 826-837

Aurisicchio C, Conte AM, De Vito C, Ottolini L (2012) Beryl from miarolitic pockets of granitic pegmatites, Elba, Italy: characterization of crystal chemistry by means of EMP and SIMS analyses. Canad Mineral 50: 1467-1488

BaČík P, MiYaWaKi R, Atencio D, CÁMara F, Fridrichová $J$ (2017) Nomenclature of the gadolinite supergroup. Eur J Mineral 29: 1067-1082

BARTON M (1986) Phase equilibria and thermodynamic properties of minerals in the $\mathrm{BeO}-\mathrm{Al}_{2} \mathrm{O}_{3}-\mathrm{SiO}_{2}-\mathrm{H}_{2} \mathrm{O}$ (BASH) system, with petrologic applications. Amer Miner 71: 277-300
BARTON M, Young S (2002) Non-pegmatitic deposits of beryllium: mineralogy, geology, phase equilibria and origin. In: GREw ES (ed) Beryllium - mineralogy, petrology and geochemistry. Mineralogical Society of America and Geochemical Society Rev Mineral Geochem 50: 591-691

BJøRLYKKe H (1935) The mineral paragenesis and classification of the granite pegmatites of Iveland, Setesdal, southern Norway. Tidsskrift 211-311

BJøRLYKKE H (1937) The granite pegmatites of the southern Norway. Amer Miner 22: 241-255

BReITER K (2008) Durbachites of the Třebíc Massif in the borehole Pozd'átky V-5 - genetic implications. Zpr geol Výzk v Roce 2007 143-147 (in Czech)

BuŘIval Z, NováK M (2018) Secondary blue tourmaline after garnet from elbaite-subtype pegmatites; implications for source and behavior of $\mathrm{Ca}$ and $\mathrm{Mg}$ in fluids. J Geosci 63: 111-122

BURT D (1978) Multisystems analysis of beryllium mineral stabilities: the system $\mathrm{BeO}-\mathrm{Al}_{2} \mathrm{O}_{3}-\mathrm{SiO}_{2}-\mathrm{H}_{2} \mathrm{O}$. Amer Miner 63: 664-676

Cámara F, Oberti R, Ottolini L, Della Ventura G, Bellatreccia F (2008) The crystal chemistry of Li in gadolinite. Amer Miner 93: 996-1004

ČERNÝ P (2002) Mineralogy of beryllium in granitic pegmatites. In: Grew ES (ed) Beryllium - mineralogy, petrology and geochemistry. Mineralogical Society of America and Geochemical Society Rev Mineral Geochem 50: 405-444

ČERNÝ P, ERCIT TS (2005) The classification of granitic pegmatites revisited. Canad Mineral 43: 2005-2026

ČERnÝ P, ANDERSON AJ, TOMASCAK PB, ChapMan R (2003) Geochemical and morphological features of beryl from the Bikita granitic pegmatite, Zimbabwe. Canad Mineral 41: 1003-1011

ČERNÝ P, LONDON D, NovÁK M (2012) Granitic pegmatites as reflection of their sources. Elements 8: 289-294

Chukanov NV, Aksenov SM, Rastsvetaeva RK, Kristiansen R, Pekov IV, Belakovskiy DI, Van KV, BychKovA YV, BRITVIN SN (2017) Crystal structure of the OH-dominant gadolinite-(Y) analogue $(\mathrm{Y}, \mathrm{Ca})_{2}(\mathrm{Fe}, \square)$ $\mathrm{Be}_{2} \mathrm{Si}_{2} \mathrm{O}_{8}(\mathrm{OH}, \mathrm{O})_{2}$ from Heftetjern pegmatite, Norway. Acta Crystallogr B73: 899-906

COOper MA, Hawthorne FC, Miyawaki R, Kristiansen $\mathrm{R}$ (2019) Cation order in the crystal structure of the Cahingganite-(Y)“. Canad Mineral 57: 371-382

Čopjaková R, ŠKoda R, VAŠInové-Galiová M, Novák M (2013) Distributions of $\mathrm{Y}+R E E$ and $\mathrm{Sc}$ in tourmaline and their implications for the melt evolution; examples from NYF pegmatites of the Třebíc Pluton, Moldanubian Zone, Czech Republic. J Geosci 58: 113-131

Čopjaková R, ŠKoda R, Vašinová-Galiová M, Novák M, CEMPíReK J (2015) Scandium- and REE-rich tourmaline replaced by Sc-rich $R E E$-bearing epidote-group mineral from the mixed $(\mathrm{NYF}+\mathrm{LCT})$ Kracovice pegmatite 
(Moldanubian Zone, Czech Republic). Amer Miner 100: 1434-1451

Dunn PJ (1976) Genthelvite and the helvine group. Mineral Mag 40: 627-636

Falster AU, BuchHolz TW, Simmons WB (2012) Mineralogical and mineral-chemical heterogeneity indicated by the distribution of accessory minerals in pegmatites of the Nine Mile pluton of the Wausau syenite complex, Marathon county, Wisconsin. Canad Mineral 5: 1499-1514

Falster AU, Simmons WB, Webber KL, Bodreaux AP (2018) Mineralogy and Geochemistry of the Erongo Sub-Volcanic Granite-Miarolitic-Pegmatite Complex, Erongo, Namibia Miarolitic Pegmatites, Erongo. Canad Mineral 56: 425-449

Franz G, Morteani G (2002) Be-minerals synthesis, stability, and occurence in metamorphic rocks. In: GREw ES (ed) Beryllium - mineralogy, petrology and geochemistry. Mineralogical Society of America and Geochemical Society Rev Mineral Geochem 50: pp 551-598

FriIs H, Makovicky E, Weller MT, LemÉe-Cailleau M-H (2010) Bohseite, IMA 2010-026. CNMNC Newsletter, 2010. Mineral Mag 74: 797-800

Giuliani G, France-Lanord C, Zimmermann JL, Cheilletz A, Arboleda C, Charoy B, Coget P, Fontan F, GIARD D (1997) Fluid composition, $\delta D$ of channel $\mathrm{H}_{2} \mathrm{O}$, and $\delta 18 \mathrm{O}$ of lattice oxygen in beryls: genetic implications for Brazilian, Colombian, and Afghanistani emerald deposits. Int Geol Rev 39: 400-424

Glass JJ, Adams JW (1953) Genthelvite crystal from El Paso county, Colorado. Notes and News. Amer Miner 38: 858-860

Grew ES, HAZEN RM (2014) Beryllium mineral evolution. Amer Miner 99: 999-1021

Guastoni A, Pennacchioni G, Pozzi G, Fioretti AM, WALTER JM (2014) Tertiary pegmatite dikes of the Central Alps. Canad Mineral 52: 191-219

Guastoni A, Secco L, Š́oda R, Nestola F, Schiazza M, Novák M, Penacchioni G (2019) Non-metamict aeschynite-( $(\mathrm{Y})$, polycrase- $(\mathrm{Y})$, and samarskite-( $\mathrm{Y})$ in NYF pegmatites from Arvogno, Vigezzo valley (Central Alps, Italy). Minerals 9: 313

HANSON SL, Zito G (2019) Beryllium mineralization in pegmatites and quartz dikes of Mount Rosa Complex Area, Colorado Front Range, Colorado, USA. Contributions to the 9 th international symposium on granitic pegmatites, PEG 2019, Pala, California, 42-44

HaWthorne FC, Huminicki DMC (2002) The crystal chemistry of beryllium. In: GREw ES (ed) Beryllium: Mineralogy, Petrology, and Geochemistry. Mineralogical Society of America and Geochemical Society Rev Mineral Geochem 50: 333-403

Hawthorne FC, Abdu YA, Ball NA, Černý P, Kristiansen $\mathrm{R}$ (2014) Agakhanovite-(Y), ideally (YCa) $\square_{2} \mathrm{KBe}_{3} \mathrm{Si}_{12} \mathrm{O}_{30}$, a new milarite-group mineral from the Heftetjern pegma- tite, Tørdal, Southern Norway: Description and crystal structure. Amer Miner 99: 2084-2088

HenRY RE (2018) Rare Earth Crystal Chemistry and Be-Si Disorder in Gadolinite from the White Cloud Pegmatite, South Platte District, Colorado, USA. PhD. thesis, University of Colorado at Boulder, Boulder, pp 1-89.

https://scholar.colorado.edu/concern/graduate_thesis_or_ dissertations $/ 3197 \mathrm{xm} 38 \mathrm{c}$

Henry D, Novák M, Hawthorne FC, Ertl A, Dutrow B, Uher P, Pezzotta F (2011) Nomenclature of the tourmaline-group minerals. Amer Miner 96: 895-913

HoLUB FV (1997) Ultrapotassic plutonic rocks of the durbachite series in the Bohemian massif: Petrology, geochemistry and petrogenetic interpretation. Sbor Geol Věd, ̌̌ Geol 31: 5-26

JanoušeK, V, Holub FV, Gerdes A (2003) K-rich magmatism in the Moldanubian Unit, Bohemian Massif - a complex story featuring variably enriched lithospheric mantle melts and their interaction with the crust. Geolines 16: 48-49

Janoušek V, Holub FV, verner K, Čopjaková R, Gerdes A, Hora JM, KoŠLer J, Tyrrell S (2019) Two-pyroxene syenitoids from the Moldanubian Zone of the Bohemian Massif: Peculiar magma derived from a strongly enriched lithospheric mantle source. Lithos 342-343: 239-262

JANOUŠEK V, HANŽL P, SvOJTKA M, HoRa JM, KoCHERGINA Erban YV, Gadas P, Holub JV, Gerdes A, Verner K, HrdLIČKová K, DALY JS, BURIÁNEK D (2020) Ultrapotassic magmatism in the heyday of the Variscan Orogeny: the story of the Třebíč Pluton, the largest durbachitic body in the Bohemian Massif. Int J Earth Sci 109: 1767-1810

LARSEN AO (1988) Helvite group minerals from syenite pegmatites in the Oslo Region, Norway. Contribution to the mineralogy of Norway, No. 68. Nor geol Tidsskr 68: $119-124$

Leichmann J, Gnojek I, Novák M, Sedlák J, Houzar S (2017) Durbachites from the Eastern Moldanubicum (Bohemian Massif): erosional relics of large, flat tabular intrusions of ultrapotassic melts-geophysical and petrological record. Int J Earth Sci 106: 59-77

LONDON D (2005) Geochemistry of alkali and alkaline earth elements in ore-forming granites, pegmatites and rhyolites. Rare Element Geochemistry and Mineral Deposits. Geological Association of Canada Short Course Notes 17: 17-43

London D (2008) Pegmatites. Canad Mineral, Special Publication 10: pp 1-347

London D, Evensen MJ (2002) Beryllium in silicic magmas and the origin of beryl-bearing pegmatites. In: Grew ES (ed) Beryllium - mineralogy, petrology and geochemistry. Mineralogical Society of America and Geochemical Society Rev Mineral Geochem 50: 445-486

MARKL G (2001) Stability of Na-Be minerals in late-magmatic fluids of the Ilímaussaq alkaline complex, South 
Greenland. Geology of Greenland Survey Bull 190: $145-158$

Markl G, Schumacher J (1997) Beryl stability in local hydrothermal and chemical environments in a mineralized granite. Amer Miner 82: 195-203

Martin RF, De Vito C (2005) The patterns of enrichment in felsic pegmatites ultimately depend on tectonic setting. Canad Mineral 43: 2027-2048

MERLET C (1994) An accurate computer correction program for quantitative electron probe microanalysis. Mikrochim Acta 114: 363-376

Müller A, Husdal T, Sunde Ø, Fris H, Andersen T, JOHANSEN TS, WERNER R, OlERUd ØTS (2017) NORWEGIAN PEGMATITES I: Tysfjord-Hamarøy, EvjeIveland, Langesundsfjord. Geological Guides 6: 1-122

NĚMEC D (1990) Neues zur Mineralogie eines Hambergitführenden Pegmatitgangs von Kracovice (bei Třebíč, Westmorava, ČSFR). Z Geol Wiss 18: 1105-1115

NovÁK M, ČECH F (1996) Scandian columbite and niobian rutile from pegmatites penetrating the Třebíč durbachite massif, western Moravia, Czech Republic. Acta Mus Morav, Sci Nat 80: 3-8

NovÁK M, FILIP J (2010) Unusual (Na,Mg)-enriched beryl and its breakdown products (beryl II, bazzite, bavenite) from euxenite-type NYF pegmatite related to the orogenic ultrapotassic Třebíč Pluton, Czech Republic. Canad Mineral 48: 615-628

NovÁK M, Povondra P (1995) Elbaite pegmatites in the Moldanubicum: a new subtype of the rare-element class. Mineral Petrol 55: 159-176

Novák M, Burns PC, Morgan GB VI (1998) Fluorine variation in hambergite from granitic pegmatites. Canad Mineral 36: 441-446

Novák M, ČERnÝ P, Selway JB (1999) The zinnwalditemasutomilite-elbaite pegmatite at Kracovice from the Třebíč durbachite massif - a complex pegmatite related to the NYF family. The Eugene E. Foord Memorial Symposium on NYF-type Pegmatites, Denver, Colorado. Canad Mineral 37: 815-816

Novák M, ŠKoda R, FiliP J, MAceK I, VAculovič T (2011) Compositional trends in tourmaline from intragranitic NYF pegmatites of the Třebíc Pluton, Czech Republic: an electron microprobe, Mössbauer and LA-ICP-MS study. Canad Mineral 49: 359-380

Novák M, ŠKoda R, Gadas, P, KrmíčeK, L, Černý, P (2012) Contrasting origins of the mixed (NYF+LCT) signature in granitic pegmatites, with examples from the Moldanubian Zone, Czech Republic. Canad Mineral 50: 1077-1094

Novák M, Cempírek J, Gadas P, ŠKoda R, VašinováGaliová M, Pezzotta F, Groat LA (2015) Boralsilite and $\mathrm{Li}$, Be-bearing "boron mullite" $\mathrm{Al}_{8} \mathrm{~B}_{2} \mathrm{Si}_{2} \mathrm{O}_{19}$, breakdown products of spodumene from the Manjaka pegmatite, Sahatany Valley, Madagascar. Canad Mineral 53: 357-374
Novák M, Cícha J, Čopjaková R, ŠKoda R, Galiová MV (2017) Milarite-group minerals from the NYF pegmatite Velká skála, Písek district, Czech Republic: sole carriers of $\mathrm{Be}$ from the magmatic to hydrothermal stage. Eur J Mineral 29: 755-766

Pekov IV, Voloshin AV, Pushcharovski DY, Rastsvetaeva RK, Chukanov NV, BelakovskiI DI (2000) New data on calcybeborosilite-( $(\mathrm{Y})(\text { REE, } \mathrm{Ca})_{2}(\mathrm{~B}, \mathrm{Be})_{2}\left[\mathrm{SiO}_{4}\right]_{2}(\mathrm{OH}, \mathrm{O})_{2}$ Moscow Univ Geol Bull C/C of Vest-Mosk Univ, Ser Geol 55: 62-70 (in Russian)

Pezzotta F, Diella V, Guastoni A (1999) Chemical and paragenetic data on gadolinite-group minerals from Baveno and Cuasso al Monte, southern Alps, Italy. Amer Miner 84: 782-789

PřikrYl J, Novák M, Filip J, Gadas P, Vašinová-Galiová M (2014) Iron+Magnesium-bearing beryl from granitic pegmatites: An EMPA, LA-ICP-MS, Mössbauer spectroscopy, and powder XRD study. Canad Mineral 52: 271-284

Rastsvetaeva RK, Pushcharovskit DY, Pekov IV, VoLOSHIN AV (1996) Crystal structure of 'calcybeborosilite' and its place in the datolite-gadolinite isomorphous series. Crystallogr Repo 41(2): 217-221

von Raumer JF, Finger F, Veselá P, Stampfli GM (2014) Durbachites-Vaugnerites - a geodynamic marker in the central European Variscan orogen. Terra Nova 26: 85-95

Simmons WB (2005) A look to pegmatite classifications. Simmons, W. B. "A look at pegmatite classifications." Crystallization Processes in Granitic Pegmatites-International Meeting Abstracts-23 $3^{\text {rd }}-29^{\text {th }}$ May, Elba Island, Italy, Museo di Storia Naturale, Milan, Italy, 1-12.

Simmons WB, LeE MT, Brewster RH (1987) Geochemistry and evolution of the South Platte granite-pegmatite system, Jefferson County, Colorado. Geochim Cosmochim Acta 51: 455-471

Simmons WB, Hanson SL, Falster AU, Webber KL (2012) A comparison of the mineralogical and geochemical character and gelogical setting of proterozoic REE-rich granitic pegmatites of the north-central and southwestern US. Canad Mineral 50: 1183-1200

ŠKoda R, Novák M (2007) Y,REE,Nb,Ta,Ti-oxide $\left(\mathrm{AB}_{2} \mathrm{O}_{6}\right)$ minerals from REL-REE euxenite-subtype pegmatites of the Třebíč Pluton, Czech Republic; substitutions and fractionation trends. Lithos 95: 43-57

ŠKoda R, Novák M, Černý P, ČERnÝ P (2004) Complex $\mathrm{Nb}-\mathrm{Ta}-\mathrm{Ti}$ oxides from pegmatite in Vepice near Milevsko, Čertovo břemeno massif. Bull mineral-petrolog Odd Nár Muz (Praha) 12: 182-185 (in Czech)

ŠKoda R, Novák M, HouZar S (2006) Granitic NYF pegmatites of the Třebíć Pluton. Acta Mus Mor Sci Geol 91: 129-176 (in Czech)

Š́oda R, Cempírek J, Filip J, Novák M, VeselovskÝ F, Č́tVRTLíK R (2012) Allanite-(Nd), $\mathrm{CaNdAl}_{2} \mathrm{Fe}^{2+}\left(\mathrm{SiO}_{4}\right)$ $\left(\mathrm{Si}_{2} \mathrm{O}_{7}\right) \mathrm{O}(\mathrm{OH})$, a new mineral from Åskagen, Sweden. Amer Miner 97: 983-988 
ŠKoda R, PlášIl J, JonsSOn E, ČOPJAKová R, LANGHOF J, VAŠINOVÁ-GALIOVÁ M (2015) Redefinition of thalénite(Y) and discreditation of fluorthalénite- $(\mathrm{Y})$ : A re-investigation of type material from the Österby pegmatite, Dalarna, Sweden, and from additional localities. Mineral Mag 79: 965-983

ŠKoda R, Plášil J, Čopjaková R, Novák M, Jonsson E, VAŠInová-Galiová M, Holtstam D (2018) Gadolinite$(\mathrm{Nd})$, a new member of the gadolinite supergroup from Fe-REE deposits of Bastnäs-type, Sweden. Mineral Mag 82: $133-145$

SMEDS SA (1990) Regional trends in mineral assemblages of Swedish Proterozoic granitic pegmatites and their geological significance. Geologiska Föreningen i Stockholm Förhandlingar 112.3: 227-242

StAnĚK J (1973) Phenakite from Třebíč, Czechoslovakia. Čas Morav muz, Vědy prŕír 58: 49-52

Szelęg E, Zuzens B, Hawthorne FC, Pieczka A, SzuszKiEWICZ A, TurniaK K, NeJbert K, ILNicki SS, FriIS H, Makovicky E, Weller MT, Lemée-Cailleau M-H (2017) Bohseite, ideally $\mathrm{Ca}_{4} \mathrm{Be}_{4} \mathrm{Si}_{9} \mathrm{O}_{24}(\mathrm{OH})_{4}$, from the Piława Górna quarry, the Góry Sowie Block, SW Poland. Mineral Mag 81: 35-46

UHER P, Chudík P, BAČík P, VACUlovič T, GALIová M (2010) Beryl composition and evolution trends: an example from granitic pegmatites of the beryl-columbite subtype Western Carpathians Slovakia. J Geosci 55: 69-80

UHER P, BAČíK P, Fridrichové J (2017) Beryl in the WestCarpathian granitic pegmatites, Slovakia: composi- tional variations and post-magmatic alteration products. PEG2017 8th International Symposium on Granitic Pegmatites, At Kristiansand, Norway. NGF Abstracts and Proceedings of the Geological Society of Norway 2: $159-160$

Wang RC, Che XD, Zhang WL, Zhang AC, Zhang H (2009) Geochemical evolution and late re-equilibration of Na-Cs-rich beryl from the Koktokay\# 3 pegmatite (Altai, NW China). Eur J Mineral 21: 795-809

WhitNey DL, EvANs BW (2010) Abbreviations for names of rock-forming minerals. Amer Miner 95: 185-187

ZACHǍ̌ A, NovÁK M (2013) Granitic NYF pegmatites in the Velké Meziříčí region, Třebíč Pluton, western Moravia (Czech Republic). Acta Mus Morav, Sci Geol 98: 83-100 (in Czech)

ZACHǍ̌ A, ŠKODA R (2019) Bohseite-bavenite from intragranitic NYF pegmatites of the Třebíc Pluton. In $9^{\text {th }}$ European Conference on the Mineralogy and Spectroscopy, Prague, Book of abstracts, p 68

ŽÁK J, Holub FV, Verner K (2005) Tectonic evolution of a continental magmatic arc from transpression in the upper crust to exhumation of mid-crustal orogenic root recorded by episodically emplaced plutons: The Central Bohemian Plutonic Complex (Bohemian Massif). Int J Earth Sci 94: 385-400

Zito G, Hanson SL (2017) Genthelvite overgrowths on danalite cores from a pegmatite miarolitic cavity in Cheyenne Canyon, El Paso County, Colorado. Canad Mineral 55: 195-206 